\title{
Voluntary exercise and depression-like behavior in rodents: are we running in the right direction?
}

\author{
Joram D Mul1,2,3 \\ 1Department of Endocrinology and Metabolism, Academic Medical Center, University of Amsterdam, Amsterdam, the Netherlands \\ 2Laboratory of Endocrinology, Department of Clinical Chemistry, University of Amsterdam, Amsterdam, the Netherlands \\ ${ }_{3}^{3}$ etherlands Institute for Neuroscience, Royal Netherlands Academy of Arts and Sciences (KNAW), Amsterdam, the Netherlands \\ Correspondence should be addressed to J D Mul: j.d.mul@amc.uva.nl
}

\begin{abstract}
Acute or chronic exposure to stress can increase the risk to develop major depressive disorder, a severe, recurrent and common psychiatric condition. Depression places an enormous social and financial burden on modern society. Although many depressed patients are treated with antidepressants, their efficacy is only modest, underscoring the necessity to develop clinically effective pharmaceutical or behavioral treatments. Exercise training produces beneficial effects on stress-related mental disorders, indicative of clinical potential. The pro-resilient and antidepressant effects of exercise training have been documented for several decades. Nonetheless, the underlying molecular mechanisms and the brain circuitries involved remain poorly understood. Preclinical investigations using voluntary wheel running, a frequently used rodent model that mimics aspects of human exercise training, have started to shed light on the molecular adaptations, signaling pathways and brain nuclei underlying the beneficial effects of exercise training on stress-related behavior. In this review, I highlight several neurotransmitter systems that are putative mediators of the beneficial effects of exercise training on mental health, and review recent rodent studies that utilized voluntary wheel running to promote our understanding of exercise training-induced central adaptations. Advancements in our mechanistic understanding of how exercise training induces beneficial neuronal adaptations will provide a framework for the development of new strategies to treat stress-associated mental illnesses.
\end{abstract}

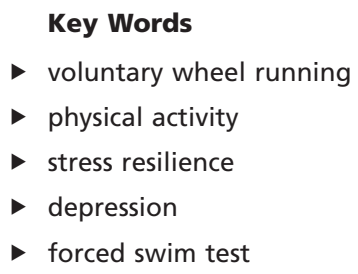

\section{Introduction}

Depression is a common neuropsychiatric disorder with enormous social and financial burden on modern society (Greenberg et al. 2003, Kessler et al. 2005, 2007). Depression is diagnosed based on a cluster of highly variable symptoms (see Diagnostic and Statistical Manual of Mental Disorders, 5th edition; DSM-VTR), which in addition to a depressed or irritable mood can include cognitive, emotional, homeostatic and psychomotor symptoms (Association 2013). To date, no single abnormality has proven robust or consistent enough to either diagnose depression in humans or validate an animal model, nor have highly penetrant genetic causes of depression have been identified (Krishnan \& Nestler 2008, Nestler \& Hyman 2010). Nonetheless, it is accepted that stress and emotional loss are strong risk factors to develop depression. Remarkably, not all humans develop posttraumatic stress disorder or depression in the face of acute or chronic adversity (Charney 2004, Yehuda 2004, 
Kessler et al. 2005). Such resilience, or the ability to successfully cope with adversity, is associated with the development of adequate molecular, behavioral and psychological adaptations to stress (Hoge et al. 2007, Krishnan \& Nestler 2008, Feder et al. 2009, Russo et al. 2012). Recently, preclinical studies have substantially advanced our understanding of molecular adaptations in the brain underlying susceptibility and resilience to stress, and this insight offers a crucial dimension for the development of novel therapeutic treatments that prevent and treat stress-related disorders (de Kloet et al. 2005, Yehuda et al. 2006, Joels et al. 2007, Krishnan et al . 2007, McEwen 2007, Krishnan \& Nestler 2008, Pittenger \& Duman 2008, Russo et al. 2012).

In 1969, Morgan demonstrated that physically unfit patients were more depressed than their fit counterparts (Morgan 1969). Since this initial observation almost 50 years ago, many studies have investigated the interaction between exercise training and mental health. Collectively, these studies indicate that exercise training is associated with beneficial effects on mental well-being (Stephens 1988, North et al. 1990, Sothmann et al. 1996, Steptoe \& Butler 1996, Steptoe et al. 1996, 1997, Fox 1999, Dimeo et al. 2001, Lawlor \& Hopker 2001, Salmon 2001, Dishman et al. 2006, Lai et al. 2006, Greenwood \& Fleshner 2008, Stranahan et al. 2008, Fuss \& Gass 2010, Perraton et al. 2010, Carek et al. 2011, Krogh et al. 2011, Blumenthal et al. 2012, Asmundson et al. 2013, Josefsson et al. 2014, Rowe et al. 2014). Nonetheless, the molecular mechanisms and the brain circuitries underlying the beneficial effects of exercise remain poorly understood. Although the development of non-invasive imaging techniques to study human brain structure and function has seen significant progress in the recent years, ethical and practical difficulties of examining the living human brain still put important limitations on our understanding of the physiology and molecular biology of the human brain. Therefore, exercise paradigms are used in rodents to model human exercise training, and such preclinical studies have substantially advanced our understanding of central molecular adaptations that potentially underlie the health benefits of exercise training in humans (Dishman et al. 2006, Patterson \& Levin 2008, Stranahan et al. 2008, Garland et al. 2011, Novak et al. 2012, Voss et al. 2013, Rowe et al. 2014). Behavioral paradigms that are frequently used to model human exercise training in rodents include, but are not limited to, forced treadmill running, forced wheel running and voluntary wheel running (VWR). This review will focus on the latter, as popularity of this behavioral paradigm is rapidly increasing, and as discussed below, this behavioral paradigm appears suited to gain insight in the exercise training-induced central adaptations. In this review, I highlight several neurotransmitter systems that have been identified in preclinical studies as putative mediators of the beneficial effects of VWR on stress resilience, and I review recent rodent studies that utilized VWR to promote our understanding of exercise traininginduced central adaptations.

\section{Self-reinforcing aspects of VWR}

Several lines of evidence indicate that rodents perceive VWR as rewarding. Rodents will run voluntarily on running wheels, and several biological factors, including genotype, gender, reproductive hormone levels, housing conditions and age of the experimental model influence running behavior (Valentinuzzi et al. 1997, Lightfoot et al. 2004, Stranahan et al. 2008). Rodents will develop a conditioned place preference for an environment associated with the after-effects of wheel running (Lett et al. 2000, Belke \& Wagner 2005, Greenwood et al. 2011, Trost \& Hauber 2014). Rodents will also work vigorously during an operant response to gain access to a running wheel (Premack 1962, Iversen 1993, Belke 1997). On a molecular level, VWR induces adaptations along the ventral tegmental area (VTA) - nucleus accumbens (NAc) axis (Werme et al. 2002, Greenwood et al. 2011, Obici et al. 2015), two key nuclei of the reward-related brain circuitry, in rodents. Lastly, mice in the wild run voluntarily on running wheels, suggesting that VWR is a natural behavior and not just restricted to laboratory animals (Meijer \& Robbers 2014). Collectively, these findings indicate that VWR is rewarding for rodents. To identify biological factors that contribute to the reinforcing nature of VWR, genomic, genetic and pharmacological approaches have started to shed light on the biology of exercise physiology (Rhodes et al. 2003, Troxell et al. 2003, Dubreucq et al. 2013, Fernandes et al. 2015, Obici et al. 2015, Ruegsegger \& Booth 2017, Ruegsegger et al. 2017). Recently, technological advances, including optogenetic and chemogenetic manipulation of specific brain circuits or neuron populations, have also been used to investigate neuronal contributions to aspects of exercise reinforcement (Hsu et al. 2014, Zhu et al. 2016, Foldi et al. 2017). These approaches will promote greater insight into the biology of VWR and enhance the utility of this animal model for the etiological examination of stress resilience conferred by exercise training. Although VWR clearly is self-reinforcing behavior in rodents, the exact nature of VWR remains unclear, and this behavior shows analogies with stereotypic and addictive behavior (Richter et al. 2014). 


\section{VWR is a physiological stressor}

VWR is frequently used in preclinical studies with the incentive that this behavioral intervention has a rewarding and voluntary nature, as discussed earlier, compared to the involuntary and stressful nature of forced wheel running or treadmill running. It should, however, be noted that VWR is clearly associated with the activation of sympathetic nervous system, resulting in epinephrine production, as well as activation of the hypothalamic-pituitary-adrenal (HPA) axis, resulting in glucocorticoid production and HPA axis feedback (Reul \& Droste 2005, Stranahan et al. 2008, Reul et al. 2015). Thus, as VWR is a threat to homeostasis, it should be considered a physiological stressor, albeit a voluntary and controllable stressor with a distinct temporal profile. This observation underlies the 'cross-stressor adaptation' hypothesis, which suggests that a stressor of sufficient intensity and/or duration (e.g. VWR) will induce adaptations along the stress response systems, and these adaptations become apparent under other similarly taxing states (Sothmann et al. 1996, Stranahan et al. 2008). However, despite several similarities, long-term VWR and chronic stress result in distinct adaptations along the HPA axis (Bhatnagar \& Dallman 1998, Droste et al. 2007). For example, long-term VWR and chronic stress training are associated with opposite effects on neurogenesis in the hippocampus (van Praag et al. 1999a,b, McEwen 2001, van Praag 2008). As discussed below, a possible explanation for these differential observations is differential activation of reward-related brain circuitry, and the subsequent induction of adaptations herein, during long-term VWR compared to chronic stress.

The temporal aspects of VWR on stress hormone biology and stress-related behavior are striking. Plasma corticosterone levels in wheel-running male SpragueDawley rats are elevated during the first 21 days of VWR, before returning to normal during the fourth week (Fediuc et al. 2006). Similarly, daily wheel-running distances in rodents generally increase during the initial 14-21 days, before plateauing around a stable level and then slowly declining again over time (Fediuc et al. 2006, Droste et al . 2007, Obici et al. 2015). The effects of VWR on caloric intake are also temporary. For example, male Wistar or SpragueDawley rats initially show hypophagia compared to sedentary controls, which generally fades away during the second or third week (Droste et al. 2007, Obici et al. 2015). In contrast, mice generally demonstrate hyperphagia (Girard \& Garland 2002, Droste et al. 2003), potentially resulting from their smaller body size and higher metabolic demands. Both rats and mice demonstrate temporal and dynamic activation of the neuroendocrine stress axis and stress-related brain circuitry, although species differences have been observed frequently (Stranahan et al. 2008, Reul et al. 2015). For example, 4 -week wheel-running mice had reduced corticotrophin-releasing hormone (CRH) mRNA expression in the paraventricular nucleus of the hypothalamus compared to sedentary controls, suggestive of an attenuated stress response, whereas this was not observed in rats running the same duration of running (Droste et al. 2003, 2007). One potential explanation for this species difference is the observation that rats and mice differ substantially in their initial and subsequent behavioral responses to running wheels. For example, male $\mathrm{C} 57 \mathrm{BL} / 6 \mathrm{~J}$ and $\mathrm{BALBc} / \mathrm{J}$ mice run vigorously on their first days of running wheel access $(\sim 4-5 \mathrm{~km})$, whereas male Wistar or Sprague-Dawley rats usually run approximately one kilometer, or even less, during their first several days of access (Droste et al. 2007, Richter et al. 2014, Obici et al. 2015, Mul et al. 2016). Unquestionably, many factors influence VWR behavior, including gender, age, metabolic condition and sensitivity to stress or reward (Valentinuzzi et al. 1997, Lightfoot et al. 2004, Stranahan et al. 2008, Novak et al. 2012, Richter et al. 2014, Obici et al. 2015).

Basal plasma corticosterone levels as well as corticosterone release in response to an acute stressor appear positively correlated with voluntary running distances (Stranahan et al. 2008). In line with these observations, rats with a loss-of-function mutation in the melanocortin 4 receptor, which have an attenuated HPA sensitivity (Ryan et al. 2014), demonstrated lower daily running distances, persistent decreases in caloric intake and dysregulation of the brain reward-related circuitry compared to wild-type controls during VWR (Obici et al. 2015). However, it has yet to be determined if these effects are related to metabolic efficiency or central adaptations associated with motivation to run or stress sensitivity. In summary, the temporal aspects of behaviors modulated by (long-term) VWR suggest that dynamic, distinct and even partially overlapping adaptations are recruited in stressrelated and reward-related brain circuitry. In humans, a similar complex picture has emerged. Many combinations of psychological and physiological stress are present, depending on the intensity and duration of an exercise regimen, which probably accounts for the wide variety of human glucocorticoid responses to exercise (Tharp 1975, Sothmann et al. 1996). In this light, how does the daily running distance of a mouse (i.e. $~ 5-10 \mathrm{~km} /$ night) compare to, for example, a twice-weekly morning run of several kilometers? Given the variety and temporal nature 
of individual responses to physical activity in humans, as well in different rodent species, it is currently difficult to compare the suitability of mouse or rat VWR models and their translational value based on the available literature.

\section{Rodent models of depression and their validity}

As listed in the DSM-VTR, depression is diagnosed based on a variety of highly variable symptoms (Association 2013). To provide more definitive evidence on the presence of a depressive-like state in an animal model, it has been suggested that a combination of emotional (anhedonia), homeostatic (body weight, sleep, appetite) or psychomotor symptoms (locomotor activity, immobility- and anxietylike behavior) or direct assessment of the reward circuitry of the brain should be measured (Nestler \& Hyman 2010, Mul et al. 2016). There is a general need for valid animal models to study the pathophysiology of depression and identify potential therapeutic interventions. In turn, animal models can help identify potential therapeutic interventions and provide mechanistic insight underlying the beneficial effects of such therapeutic interventions.

Unfortunately, the development of animal models of depression with construct, face and predictive validity remains a major challenge (for excellent review on this topic see (Nestler \& Hyman 2010). As a result, current animal models have substantial limitations ranging from weak validation to poor predictive power of drug efficacy in human disease (Markou et al. 2009, Nestler \& Hyman 2010, Belzung \& Lemoine 2011). Construct (or etiologic) validity refers to disease relevance of the methods by which a model is constructed. In other words, a model with construct validity would ideally recreate the etiologic processes in an animal model that cause disease in humans, thus replicating neural and behavioral features of the illness (Chadman et al. 2009, Nestler \& Hyman 2010). Face validity refers to the recapitulation of important anatomical, biochemical, neuropathological or behavioral features of human disease (Chadman et al. 2009, Nestler \& Hyman 2010). Because of the absence of known neurobiological abnormalities in humans, behavioral features reminiscent of human disorder are commonly required to achieve face validity. Predictive (or pharmacological) validity refers to a response of animal models to treatments that predicts the effects of those treatments in humans (Chadman et al. 2009 , Nestler \& Hyman 2010). Unfortunately, adherence to these validities is far too often not addressed in depressionrelated rodent studies, and should be discussed to put the results in a bigger perspective.
To date, several etiologically valid models utilizing chronic stress are commonly used in rodents to induce maladaptive adaptations in the reward- and stress-related circuitry, often resulting in a depressive-like state. Chronic social defeat stress (CSDS) is a common paradigm that involves subjecting rodents to bouts of physical and social subordination, as well as stressful sensory housing and induces long-term physiological and behavioral depression-like phenotypes, including social avoidance, anhedonia and homeostatic and anxiety-like symptoms (Kudryavtseva et al. 1991, Koolhaas et al. 1997, Rygula et al. 2005, Krishnan et al. 2007, Mul et al. 2016). CSDS is sometimes used to investigate the molecular processes underlying 'resilience', as some rodents fail to develop physiological and behavioral depression-like phenotypes (Krishnan et al. 2007). A limitation of the social defeat paradigm is that it relies on intermale confrontation. However, a recent study reported that vicarious social defeat can induce depression-related outcomes in female mice (Iñiguez et al. 2017). CSDS stress exhibits features of construct, face and predictive validity (Nestler \& Hyman 2010). Because several behavioral maladaptations following CSDS are sensitive to chronic, but not acute, antidepressant treatment, this paradigm is suitable to study the aspects of depression and posttraumatic stress disorder (Berton et al. 2006, Rygula et al. 2006).

Chronic unpredictable stress (CUS), which usually involves a series of daily unpredictable physical stressors (e.g. physical restraint, cage tilt, cold temperature, social stress, foot shock, no bedding) for weeks, also induces long-term physiological and behavioral depression-like phenotypes, including anhedonia, and homeostatic and anxiety-like symptoms (Willner et al. 1992, Willner 2005). CUS exhibits features of construct, face and predictive validity (Nestler \& Hyman 2010). The stressors during CUS are usually milder compared to intense social defeat stress, but of longer duration, so researchers should decide which model is a more appropriate tool to investigate the neurobiology of behavior of interest.

Early-life stress, which includes maternal separation or limited bedding and nesting, induces life-long behavioral and neuroendocrine abnormalities in rodents (Meaney 2001, Krugers et al. 2017, Walker et al. 2017). This animal model exhibits features of construct, face and predictive validity.

Rodents are social animals. Therefore, chronic social isolation can induce maladaptive adaptations in the brain (e.g. $\Delta$ FosB downregulation in reward-related circuitry), resulting in a variety of aberrant behavior, including anxiety-like behavior and anhedonia (Wallace et al. 2009, 
Vialou et al. 2010). This animal model exhibits features of construct, face and predictive validity (Wallace et al. 2009).

To date, several reports have utilized the 5-day repeated forced swim stress (5d-RFSS) paradigm with the intention to induce a depression-like state in rodents (Stone \& Lin 2011, Sun et al. 2011, Serchov et al. 2015). During this test, animals are forced to swim for a brief time on several successive days, and behavior during forced swim stress is analyzed. Notably, 5d-RFSS induced increased immobility during successive forced swim stress in young, adult male C57BL/6J and BALB/ cJ mice, but failed to induce emotional (anhedonia), homeostatic (body weight, food intake) or psychomotor (locomotor and anxiety-like behavior during an open-field test) symptoms (Mul et al. 2016). A recent commentary by Delcourte and colleagues suggested this result was obtained because the mice were forced to swim during the inactive light phase (Delcourte et al. 2017). The authors then went on to show immobility behavior from forced swim tests (i.e. coping behavior) of mice that were forced to swim during the night phase (Delcourte et al. 2017). Unfortunately, no other parameters of depression-like behavior were reported in this commentary (Delcourte et al. 2017). As discussed below, increased immobility during forced swim tests should be interpreted as coping behavior, and without the additional presence of emotional, homeostatic or psychomotor symptoms, should not be accepted as bona fide evidence of a depression-like state. As such, the $5 \mathrm{~d}$-RFSS paradigm exhibits features of predictive validity (Stone \& Lin 2011, Sun et al. 2011, Serchov et al. 2015, Mul et al. 2016, Delcourte et al. 2017), but at least in young male $\mathrm{C} 57 \mathrm{BL} / 6 \mathrm{~J}$ and $\mathrm{BALB} / \mathrm{cJ}$ mice, appears to lack construct or face validity (Mul et al. 2016).

Repeated restraint stress induces stress-related behavioral abnormalities in rodents, including anhedonia and anxiety-like behavior (Seo et al. 2016) and exhibits features of construct, face and predictive validity.

Finally, animal models involving genetic (e.g. animal models with mutations) or pharmacological (e.g. continuous administration of corticosterone) modulation of the HPA axis are also utilized and can induce anhedonia and modify stress-related behavior in rodents (Muller \& Holsboer 2006, Nicolas et al. 2015). However, abnormalities in the HPA axis are highly variable in human depression, which means that researchers using HPA axis abnormalities to argue for construct or face validity should explicitly defend these choices and ideally rely on additional validators (Nestler \& Hyman 2010).

\section{Current assessment of depression-like behavior in rodents}

The symptoms of depression that can be objectively measured in rodents are limited to emotional (anhedonia), homeostatic (sleep, appetite, body weight) and psychomotor (locomotor activity and anxietylike behavior) symptoms (Nestler \& Hyman 2010). Nonetheless, several treatment-based screens (i.e. forced swim test (FST), tail-suspension test (TST) and learned helplessness test (LHT)) are commonly used to report on depression-like behavior in rodents, often without any additional measurements of emotional, homeostatic or psychomotor symptoms. In the FST and TST, animals are forced to swim or suspended from their tail, respectively, and behavioral aspects, such as mobility, are quantified as the animal deals with the acute inescapable stressor. In the LHT, animals are exposed to inescapable stress, usually footshock stress, which eventually results in behavioral despair. Of all these treatment-based screens, the FST is by far the most popular, due to the ease to perform the test in a high-throughput manner and interlaboratory reliability. Unfortunately, behavioral observations in the FST are often incorrectly interpreted as bona fide depressive-like behavior. This is surprising and unfortunate, as plethora of behavioral and mechanistic studies have demonstrated that increased immobile behavior during the FST is coping behavior and does not provide any conclusive evidence on depression-like behavior (Hawkins et al. 1978, Molendijk \& de Kloet 2015, de Kloet \& Molendijk 2016). To clarify, the FST has predictive validity (i.e. it can be used to screen for compounds with antidepressant potential), but lacks construct (i.e. patients usually do not become depressed from repetitively being forced to swim) or face (i.e. increased immobility in a swimming pool is not a known human depressive phenotype) validity (Nestler \& Hyman 2010). The traditional 2-day FST entails an initial swim session, and a second session (retest) $24 \mathrm{~h}$ later to test the acquired immobility (Porsolt et al. 1977b, 1978a,b). In between the sessions, substances can be administered to test their effect on escape-related behavior. Because some antidepressants were shown to reduce immobility in the retest (Porsolt et al. 1977b), the 2-day FST can be used as a screening procedure to test antidepressant potential of substances or treatments (Slattery \& Cryan 2012). An open-field test should always be used to control for general changes in activity, as changes could generate false-positive or false-negative results in the FST. In mice, a 1-day FST is commonly used (Porsolt et al. 1977a, 1978b). One-day FSTs are also used in rats. The above-mentioned 
critical notions about the face and construct validity of the FST can also be applied to the TST.

To examine the beneficial effects of VWR on stressrelated behavior, rodents can be exposed to acute stress, followed by subsequent assessment of stress hormone dynamics and stress-related behavior. Common examples of acute stress are a single bout of social defeat (Lancel et al. 2003) or a single session of restraint stress (Fediuc et al. 2006).

\section{Effects of VWR in chronic stress-induced models of depression}

\section{Chronic social defeat stress (CSDS)}

In male C57BL/6 mice, electrophysiological analyses of striatal neurons revealed that $24 \mathrm{~h}$ of VWR immediately following 3 days of social defeat could rescue stressinduced changes in sensitivity of GABA synapses to cannabinoid receptor activation (Rossi et al. 2008). In this same mouse strain, 2-h access to a running wheel immediately after each defeat session during 10 days of CSDS potentially ameliorated stress-related effects on social behavior, although the study seems to suffer from being underpowered (Otsuka et al. 2015). We have observed in male C57BL/6J mice that 21 days of VWR, prior to 10 days of CSDS, prevented the onset of anhedonia and social avoidance (Mul, personal communication). Furthermore, these effects were dependent on functional accumulation of the long-lasting transcription regulator $\Delta \mathrm{FosB}$ in the nucleus accumbens (Mul, personal communication), suggesting that VWR induction of $\triangle$ FosB in the nucleus accumbens is a key mechanistic adaptation underlying pro-resilient action of VWR in mice (see also ucleus accumbens section). In a mild social conflict model, male wheel-running and sedentary C57BL6/N mice showed equal increases in stress responses to the 15-min social conflict (Lancel et al. 2003). However, VWR for 28 days increased plasma corticosterone levels, but not adrenocorticotrophic hormone levels and revealed opposite changes in non-rapid eye-movement sleep in response to the social conflict compared to sedentary controls (Lancel et al. 2003). These findings suggest that adaptations in the HPA axis of wheel-running mice positively affects sleep quality and has protective effects.

\section{Chronic unpredictable stress (CUS)}

In C57BL/6J mice that underwent CUS for 42 days, concurrent VWR delayed but not prevented the induction of anhedonia compared to sedentary mice (Solberg et al. 1999). In the same study, VWR decreased immobility scores during a 1-day FST, independent of CUS application (Solberg et al. 1999). Another study with male C57BL/6 mice demonstrated that a 6 -week CUS paradigm induced a depression-like state, as indicated by anhedonia in the sucrose preference test and decreases in body weight, while VWR for $2 \mathrm{~h}$ every day during a 6-week CUS paradigm prevented this (Huang et al. 2017). VWR also prevented and blunted increases in immobility scores in the FST and TST, respectively, compared to sedentary stressed animals (Huang et al. 2017). Notably, just VWR for $2 \mathrm{~h}$ did not alter behavior in the sucrose preference test, FST or TST compared to unstressed controls (Huang et al. 2017).

In male Sprague-Dawley rats, VWR for 3 weeks prior to the start of CUS and during 4 subsequent weeks of CUS did not prevent the onset of anhedonia compared to unstressed wheel-running controls (Grippo et al. 2003). However, CUS negatively affected running behavior and no sedentary controls were included in this study (Grippo et al. 2003), so it cannot be assessed if VWR was protective compared to sedentary conditions. Zheng and colleagues also used male Sprague-Dawley rats and allowed the rats to run during 1 acclimatization week, 4 CUS weeks and 2 recovery weeks (Zheng et al. 2006). This study revealed protective effects of VWR against CUS-induced anhedonia and blunted body weight gain (Zheng et al. 2006).

\section{Early-life stress}

Early-life stress has long-lasting consequences for later cognition and hippocampal plasticity, including changes in adult hippocampal neurogenesis (Korosi et al. 2012). Notably, in group-housed female C57BL/6J mice that had been exposed to early-life stress, VWR for 42 days at 8 months of age failed to induce hippocampal proliferation compared to age-matched control animals that had not been exposed to early-life stress (Abbink et al. 2017). These observations suggest that long-lasting adaptations are induced by early-life stress, which prevent the beneficial effects of VWR on hippocampal flexibility many months after the occurrence of early-life stress.

\section{Social isolation}

Eight weeks of social isolation promotes susceptibility to social defeat stress in young-adult C57Bl/6J mice (Vialou et al. 2010). Similarly, 10-12 weeks of social isolation induces anxiety-like behavior and anhedonia in SpragueDawley rats (Wallace et al. 2009). Remarkably, prior 
social isolation as well as additional stressors during the experiment (i.e. handling and injection) can modulate the effects of VWR on neurogenesis in the hippocampus of male Sprague-Dawley rats (Stranahan et al. 2006). For example, male Sprague-Dawley rats that were individually housed for 1 week before the onset of VWR demonstrated increased neurogenesis in the hippocampus after 48 , but not 24, days of VWR (Stranahan et al. 2006). Changes in circadian corticosterone dynamics are a likely explanatory mechanism for these molecular observations (Stranahan et al. 2006, 2008). These findings indicate that housing conditions prior to the onset of VWR, an experimental variable often not mentioned in published experimental designs, as well as additional stressors during an experiment (i.e. handling and injection) can have profound and differential effects on subsequent molecular and behavioral responses to VWR.

\section{Repeated forced swim stress}

5d-RFSS induces coping behavior (i.e. increased immobility during forced swim tests) in wild-type male C57BL/6J and $\mathrm{BALB} / \mathrm{cJ}$ mice without the induction of emotional, homeostatic or psychomotor symptoms (Mul et al. 2016). Whether 5d-RFSS can induce emotional, homeostatic or psychomotor symptoms in aged rodents or genetic lines with increased stress susceptibility, or when it is applied during the dark phase, remains debated (Serchov et al. 2015, Mul et al. 2016, Delcourte et al. 2017). In line with the predictive validity of 5d-RFSS (Stone \& Lin 2011, Sun et al. 2011, Serchov et al. 2015), 5d-RFSS induced coping behavior and VWR for 28 days after 5d-RFSS normalized immobility scores during a final swim test toward nonstressed controls (Mul et al. 2016). Similarly, male Wistar rats that were exposed to daily swim stress for 10 days developed coping behavior (i.e. increased immobility), and 21 days of subsequent VWR ameliorated this behavior (Eldomiaty et al. 2017).

\section{Effects of VWR in treatment-based screens}

\section{Forced swim test (FST) and tail-suspension test (TST)}

Several studies have reported that VWR, following various durations, can alter subsequent behavior in treatmentbased screens like the FST, TST and LHT. For example, in male C57BL6/J mice or Swiss mice, 14-21 days of VWR decreases immobility scores in a 1-day FST and TST compared to sedentary controls (Duman et al. 2008,
Cunha et al. 2013, Yau et al. 2014). Notably, the magnitude of these effects was similar to the antidepressant amitriptyline (Duman et al. 2008). VWR, presumably for 28 days, decreased immobility scores in a 1-day FST in wild-type mice, but VWR was ineffective in mice with heterozygous loss of the VGF nerve growth factor $\left(V g f^{+-}\right)$ (Hunsberger et al. 2007).

In rats, VWR is also associated with decreased immobility scores. In Sprague-Dawley rats, VWR for 21 days lowered immobility scores during the second day of a 2-day FST at the onset of darkness (Chen et al. 2016). In Flinders Sensitive Line and Flinders Resistant Line rats, the former being a genetic animal model of depression and the latter a control line, VWR for 30 days decreased and increased, respectively, immobility behavior in a 1-day FST compared to their respective sedentary controls (Bjornebekk et al. 2005). In an additional study with Flinders Sensitive Line rats, 28 days of VWR also decreased immobility behavior (Bjornebekk et al. 2010). These observations suggest that altered genetic makeup of Flinders Sensitive Line and Flinders Resistant Line rats seems to have opposite effects on their coping behavior in response to acute swim stress. In a rat model of fetal alcohol spectrum disorder, VWR for 12 days ameliorated behavioral abnormalities in a 1-day FST, but this effect was specific for males (Brocardo et al. 2012).

The effects of VWR on FST behaviors are unfortunately not always consistent. For example, several studies with C57BL6/J mice failed to observe differences in immobility scores between wheel-running and sedentary mice during a 1-day FST (Fuss et al. 2010, Nishijima et al. 2013b). Similarly, VWR for 21 days in several cohorts of male C57BL/6J cohort did also not modulate immobility scores compared to sedentary controls days during a light-phase 1-day FST (Mul, personal communication). Lastly, in male Wistar rats, VWR for 21 days did not affect behavior in a 1-day FST compared to sedentary controls (Eldomiaty et al. 2017). These inconsistent observations might be explained by methodological differences, such as time of day when test is performed, sound isolation of the room, acclimatization to test room and behavior scoring methods (automated vs manual). It is therefore important to report such experimental factors in detail during publication.

\section{Learned helplessness test (LHT)}

In the LHT, behavioral depression or learned helplessness is induced by exposure to stressful events (e.g. foot shock) over which the organism has no control (Greenwood \& 
Fleshner 2008). In male C57BL6/J mice, 21 days of VWR decreases failure and latency scores in an LHT compared to sedentary controls (Duman et al. 2008). Female Sprague-Dawley rats that had access to running wheels for 9-12 weeks demonstrated shorter latency to escape foot shock, and this was associated with altered norepinephrine and serotonin dynamics in several brain regions (Dishman et al. 1997). In male Sprague-Dawley rats, VWR for 6 weeks reduced the effects of uncontrollable stress on shuttle box escape and freezing behavior (Greenwood et al. 2003). This study also identified adaptations in the serotonergic brain circuitry as a likely mediator of these effects (Greenwood et al. 2003). The protective effects of VWR on shuttle box escape behavior and molecular adaptations in the serotonergic brain circuitry appear to be sensitive to the duration of prior VWR, as these effects were observed after 6 , but not 3 , weeks of VWR in adult male Fischer F344 rats (Greenwood et al. 2005). One study reported that VWR for 3 weeks in C57BL6/J mice did not affect LH behavior compared to sedentary controls (Fuss et al. 2010).

\section{Effects of VWR on anhedonia}

Anhedonia is defined as the inability to experience pleasure from an activity usually found enjoyable. In rodents, stress-induced anhedonia is commonly assessed by analyzing sucrose preference or sexual behavior, which are examples of consummatory and motivational anhedonia, respectively. Yau and colleagues reported that VWR for 14 days increased preference for a $2 \%$ sucrose solution (i.e. prohedonia) in wild-type mice suggested to have a C57BL6/J background, an observation that was likely potentiated by an unusually low $(\sim 75 \%)$ baseline sucrose preference (Yau et al. 2014, Mul et al. 2016). In addition, given the caloric value of the sugar solution, it is difficult to determine if VWR truly altered emotionality of the mice or the increased consumption of the sugar solution reflects changes in caloric demands. In several cohorts of wild-type male C57BL/6J, which demonstrated a basal preference of around $90 \%$ that is typical for C57BL/6J mice (Pothion et al. 2004, Mul et al. 2016), VWR for 21 days did not modulate preferences for a $1 \%$ sucrose solution compared to sedentary control days during a 3-day sucrose preference test (Mul, personal communication). Therefore, it might be possible that the effects of VWR on sucrose preference are only visible during low baseline preferences. In addition, palatable solutions without caloric content could potentially shed light on the effects of VWR on anhedonia.

C) 2018 Society for Endocrinology Published by Bioscientifica Ltd. Printed in Great Britain

\section{Responses to acute stress following VWR}

\section{Restraint stress}

VWR for 4 weeks induced adaptations along the HPA axis in male C57BL6/N mice and increased plasma corticosterone levels in response to 30-min restrain stress (Droste et al. 2006). In male Sprague-Dawley rats, conflicting results have been observed. VWR for 35 days, plus 7 days of VWR following recovery from carotid artery surgery, blunted plasma adrenocorticotropic hormone (ACTH) excursions, but did not affect plasma corticosterone excursions, following a 20-min restraint stress (Fediuc et al. 2006). In contrast, 30-min restraint stress induced similar increases in plasma corticosterone and ACTH levels in 42-day trained and sedentary rats (Campeau et al. 2010). Because the running duration is similar in both rat studies, stress associated with the surgical procedure or with the collection of blood (relatively stress-free via carotid cannula vs tail vein puncture) could be potential methodological explanations for the differential results.

\section{Novelty stress}

VWR for 4 weeks induced adaptations along the HPA axis in male C57BL6/N mice and blunted plasma corticosterone levels in response to 30-min exposure to a clean novel environment, independent of the presence of a clean running wheel in that novel environment (Droste et al. 2006). A study in 28-day trained male Sprague-Dawley rats showed less exploratory behavior, and more lying on the cage floor, in response to 30-min exposure to a clean environment (Droste et al. 2007). Also in male SpragueDawley rats, 42 days of VWR blunted corticosterone and ACTH responses to a clean novel environment or 85dBA noise (Campeau et al. 2010). These observations indicate that VWR modulates behavioral response to mild novelty stress.

\section{Anxiety-like behavior}

Several studies have investigated the effects of VWR on anxiety-like behavior. Binder and colleagues found that 28 days of VWR in male C57BL6/N mice resulted in decreased anxiety-related behavior and 'impulsiveness', as measured in the open-field test, the modified hole board test, the elevated plus maze and the dark-light box (Binder et al. 2004). Similarly, 21 days of VWR in male C57BL6/J mice decreased anxiety-related behavior in the open-field test and elevated plus maze, although timing 
of the experiments during or after wheel access seemed to influence mouse behavior (Duman et al. 2008). In male Sprague-Dawley rats, VWR for 28 or 56 days generally showed decreased activity in the elevated plus maze and open-field test, in support of 'defensive behavior' or decreased impulsiveness (Burghardt et al. 2004).

In contrast, one report demonstrated that 21-28 days of VWR in male C57BL6/J mice produced increased anxiety-related behavior, as measured in the open-field test, the elevated O-maze and the dark-light box (Fuss et al. 2010). The inconclusive effects of VWR on anxiety-like behavior likely result from methodological differences. As such, it is important to report when exactly the behaviors were assessed during the day.

\section{Brain circuitry, molecular adaptations and neurotransmitters mediating beneficial effects of VWR}

\section{Hippocampus}

The hippocampus is as a major site where changes occur that are induced by exercise and is a key brain region involved in learning and memory. Within the hippocampus, the neurotransmitter brain-derived neurotrophic factor (BDNF) is a key mediator of the beneficial effects of VWR on learning, memory and stressrelated behavior (Cotman \& Berchtold 2002, Duman \& Monteggia 2006, Duzel et al. 2016, Cooper et al. 2017). In male C57BL/6J mice, VWR for 27 days increased BDNF protein levels in whole hippocampus samples (Fuss et al. 2010) and hippocampal BDNF protein levels remained elevated for 14 days following cessation of VWR (Berchtold et al. 2010). In the same mouse strain, VWR increases Bdnf mRNA in the dentate gyrus and CA1 of the hippocampus, the latter being observed after 21 days, but not 7 days, of running (Duman et al. 2008). The same group went on to show that VWR for 7 days increased Bdnf and Vgf mRNA, and BDNF and VGF protein levels, in the hippocampus of male C57BL/6J mice (Hunsberger et al. 2007). VGF is a secreted neuropeptide involved in energy balance and synaptic plasticity (Hahm et al. 1999, Alder et al. 2003), making it a likely candidate for some of the effects of VWR on energy homeostasis and stress sensitivity.

VWR-mediated increases in hippocampal BDNF and subsequent neuronal adaptations seem to play a role during behavioral responding to an acute stressor, as decreased immobility during an FST following 21 days of VWR was not observed in mice heterozygous for a deletion of Bdnf (Duman et al. 2008). Furthermore, intraperitoneal administration of the specific MAPK kinase inhibitor PD184161 during a 2-day FST abolished the effects of VWR on immobility behavior during the retest, whereas it had no effect in sedentary controls (Duman et al. 2008). Finally, VWR for 28 days had no effect on FST behavior in $\mathrm{Vgf}+$ - mice (Hunsberger et al. 2007). However, it is possible that this behavior reflects a developmental issue, as $\mathrm{Vgf}^{+/-}$ mice demonstrated baseline changes in FST behavior as well as normal VWR induction of hippocampal VGF protein (Hunsberger et al. 2007).

In male C57BL/6J mice, VWR for 14 days increased BDNF protein in the dentate gyrus, but not in the whole hippocampus, and this effect was independent of wholebody loss of adiponectin (Yau et al. 2014). Adiponectin is an adipocyte-secreted protein with profound beneficial effects on glucose and energy homeostasis (Kubota et al. 2007), as well as protective effects in the brain (Arnoldussen et al. 2014). Because adiponectin can mimic many of the metabolic effects of exercise, Yau and colleagues investigated the role of adiponectin during VWR and demonstrated that adiponectin is an important mediator of the effects of VWR on hippocampal neurogenesis and in treatment-based screens (Yau et al. 2014). Furthermore, conditional adiponectin-knockout mice had decreased hippocampal insulin-like growth factor-1 (IGF-1), a growth factor upregulated in the hippocampus by chronic antidepressant treatment (Khawaja et al. 2004) and compromised activation of hippocampal AMPK following 14 days of VWR (Yau et al. 2014). Another study observed normal hippocampal neurogenesis in adiponectinknockout mice during environmental enrichment (Nicolas et al. 2015). IGF-1 is further implicated in the beneficial effects of VWR on stress-related behavior, as subcutaneous anti-IGF-1 antibody administration using a mini-pump during 28 days of VWR prevented the effects of VWR on immobility scores in a 1-day FST in male C57BL/6J mice (Duman et al. 2009). Fuss and colleagues observed that 27 days of VWR in C57BL/6J mice was associated with decreased cell death and increased cell differentiation, but not cell proliferation, in the subgranular zone of the dentate gyrus (Fuss et al. 2010). Furthermore, 14 days of VWR in C57BL/6J mice was associated with clear increases in newborn cells, cell differentiation and proliferation in the dentate gyrus, and these effects were abolished in adiponectin knockout mice (Yau et al. 2014). VEGF also plays a likely role, as peripheral blockade of VEGF abolished VWR-induced hippocampal neurogenesis in group-housed male C57BL/6J mice (Fabel et al. 2003).

Similar observations have been observed in wheelrunning rats. In male Sprague-Dawley rats, already 2 
nights of VWR are sufficient to increase $B d n f$ mRNA in the hippocampus and neocortex compared to untrained rats (Neeper et al. 1995, 1996). Moreover, VWR induction of hippocampal BDNF protein levels continued to rise with VWR duration, measured up to 90 days of VWR (Berchtold et al. 2005). Interestingly, intermittent access to running wheels induced hippocampal BDNF protein to similar level as continuous access (Berchtold et al. 2005). An elegant recent study demonstrated that moderate intermittent amounts of VWR, which might more closely relate to human exercise paradigms, are superior to continuous daily VWR at promoting hippocampal neurogenesis during 30-day access to running wheels (Nguemeni et al. 2017). In Wistar rats, 4-week VWR, prior to 4 weeks of restraint stress, increased mobile behavior during an FST compared to sedentary controls, and these effects were associated with increased hippocampal BDNF protein levels (Lapmanee et al. 2017).

In Flinders Resistant Line rats, but not Flinders Sensitive Line rats, VWR increased Bdnf mRNA and cell proliferation in the dentate gyrus, but not in other regions of the hippocampus or neocortex (Bjornebekk et al. 2005). Consistently, both research teams observed a positive correlation between daily running distances and Bdnf mRNA in the dentate gyrus (Neeper et al. 1995, Bjornebekk et al. 2005, 2008). Furthermore, increased immobility during a 1-day FST and increased BrdUimmunoreactive cells in the dentate gyrus following 30-35 days of VWR was positively associated with hippocampal neuropeptide Y (NPY) and NPY-Y1 receptor mRNA in Flinders Sensitive Line rats, (Bjornebekk et al. 2006, 2010). NPY is a neuropeptide involved in energy homeostasis as well as stress-related behavior (Bosker et al. 2011, Morton et al. 2014). Stress-related behavioral differences between Flinders Sensitive Line and Flinders Resistant Line rats might partially be explained by a single-nucleotide polymorphism in the NPY promoter, resulting in altered NPY function in the hippocampus (Melas et al. 2013).

\section{Locus coeruleus}

The brainstem nucleus locus coeruleus is major source of norepinephrine and is involved in stress responses, motivation and learning and memory. In SpragueDawley rats, VWR for 21 days increased prepro-galanin mRNA in the locus coeruleus (Sciolino et al. 2012, 2015). Although sedentary and trained rats displayed similar behavior in the elevated plus maze, shock probe defensive burying and defensive withdrawal tests, VWR did have a protective effect when pharmacological or physical stress was induced (Sciolino et al. 2012, 2015).

\section{Prefrontal cortex}

Twenty-one days of VWRor chronicintracerebroventricular administration of galanin attenuated stress-evoked dopamine flux in the medial prefrontal cortex (PFC) and prevented stress-evoked loss of dendritic density in this region following stress (Sciolino et al. 2015). However, intracerebroventricular administration of a galanin receptor antagonist failed to prevent the effects of VWR on stress-evoked dopamine flux, suggesting that these VWRmediated adaptations are likely galanin independent (Sciolino et al. 2015).

\section{Dorsal raphe nucleus}

Hyperactivity of serotonin neurons in the dorsal raphe nucleus are implicated in mediating learned helplessness behaviors (for excellent review see (Greenwood \& Fleshner 2011). VWR prevents learned helplessness (Dishman et al. 1997, Greenwood et al. 2003, 2005, Duman et al. 2008), and attenuated activity of serotonergic neurons in the dorsal raphe nucleus during VWR might be a likely underlying mechanism (Greenwood \& Fleshner 2011).

\section{Nucleus accumbens}

Long-term VWR promotes accumulation of the transcription regulator $\triangle \mathrm{FosB}$ in the nucleus accumbens, an important brain reward-associated area (Werme et al. 2002, Greenwood et al. 2011, Obici et al. 2015). VWR also induces $\Delta$ FosB in the hippocampus, most notably the dentate gyrus (Nishijima et al. 2013a). $\Delta$ FosB, a particularly stable Fos family member, heterodimerizes with Jun family proteins to form activator protein-1 (AP-1) transcription factor complexes and regulates the transcription of hundreds of genes (Hope et al. 1994, McClung \& Nestler 2003). Many preclinical studies support the notion that $\Delta \mathrm{FosB}$ in the nucleus accumbens is strongly implicated in neuronal adaptations to repetitive exposure to drugs of abuse, natural rewards and stress (Robison \& Nestler 2011, Russo \& Nestler 2013, Nestler 2015). Using murine models of 21-day VWR prior to 10-day CSDS, we have observed that VWR promotes resilience to CSDS-induced anhedonia and social isolation in male C57BL/6J mice and that viral-mediated functional loss of $\Delta \mathrm{FosB}$ in the nucleus accumbens during VWR negated these protective effects (Mul, personal communication). This suggests that 
VWR induction of nucleus accumbens $\Delta$ FosB plays a key role in some of the beneficial effects of VWR on stress susceptibility in mice. On a circuitry level, a hippocampus - amygdala - nucleus accumbens pathway mediates some of the mnemonic aspects of stress-induced behavioral impairments (Ramirez et al. 2015), confirming the gateway position of neurons in the nucleus accumbens, a key output nucleus of the brain reward circuitry, to translate input from other stress-related brain nuclei into behavior. Involvement of the infralimbic cortex cannot be excluded in these effects, as ventromedial PFC outputs to downstream limbic targets, including the nucleus accumbens, modulates stress resilience during enriched environmental housing conditions, which included running wheels (Lehmann \& Herkenham 2011).

Although VWR-mediated upregulation of BDNF and VGF in the hippocampus are clearly associated with beneficial effects on stress-related behaviors (Duman \& Monteggia 2006, Hunsberger et al. 2007, Cooper et al. 2017), upregulation of these proteins in the nucleus accumbens appears to be associated with negative behavioral outcomes (Eisch et al. 2003, Berton et al. 2006, Krishnan et al. 2007, Wook Koo et al. 2016, Jiang et al. 2017). To the best of my knowledge, NAc BDNF protein levels following VWR have not been adequately assessed to date. First, Marais and colleagues reported that 6-week VWR increased NAc BDNF protein levels in rats compared to sedentary controls, although it has to be noted that all experimental animals had been subjected to maternal separation (Marais et al. 2009). As noted earlier, increased striatal BDNF activity is associated with stress-susceptible phenotypes, and the occurrence of early-life stress before the onset of VWR makes it difficult to draw firm conclusions from this study. Second, studies investigating NAc Bdnf mRNA remain inconclusive, as striatal Bdnf mRNA levels were not changed after 7-day VWR (Neeper et al. 1996), either too low to be analyzed (Van Hoomissen et al. 2003) or not compared to sedentary controls (Roberts et al. 2012). In the latter study, rats selected for high or low VWR activity did not show differences in NAc Bdnf mRNA following 6 days of VWR and 1 day rest (Roberts et al. 2012). Finally, VWR for 21 days increased $B d n f$ mRNA in the ventral tegmental area/substantia nigra areas, an area with abundant $B d n f$ expression, although it has to be noted that these rats were subjected to a daily saline injection paradigm and a subsequent stress effect cannot be excluded (Van Hoomissen et al. 2003). In summary, more work is required to determine the role of BDNF dynamics in the ventral tegmental area - nucleus accumbens axis on stress-related behavior in response to VWR.

\section{Exercise myokines}

Recent studies have identified several myokines (i.e. muscle-derived signaling molecules) that appear to be released during exercise and induce beneficial effects in the brain. Agudelo and colleagues demonstrated, using sedentary genetic mouse models, that muscle peroxisome proliferator-activated receptor gamma coactivator 1-alpha 1 (PGC-1a1) can modulate kynurenine metabolism, thereby mediating resilience to stress-induced depression (Agudelo et al. 2014). Although molecular evidence for upregulation of muscle kynurenine-related enzymes and plasma kynurenic acid was presented following 56 days of VWR (and with selection of high runners), direct evidence in mice that kynurenine metabolism is underlying the beneficial effects of VWR on stress resilience was not provided (Agudelo et al. 2014). In humans, exercise training clearly affects muscle kynurenine metabolism (Agudelo et al. 2014, Schlittler et al. 2016). However, extreme endurance cycling (150-km road cycling time trial), but not eccentric exercise (100 drop jumps), increased plasma kynurenic acid and lowered plasma quinolinic acid-to-kynurenic acid ratio levels (Schlittler et al. 2016), suggesting that only high-intensity longduration physical activity might acutely modulate plasma kynurenic metabolism. Similarly, 12-week training periods, at three different levels of intensity (mild, moderate, vigorous), were not associated with long-lasting changes in plasma kynurenine or kynurenic acid levels (Millischer et al. 2017). Finally, plasma kynurenic acid was increased after marathon running, but not after a short treadmill exercise test (Lewis et al. 2010). Although a direct role for kynurenic acid metabolism during exercise remains to be demonstrated in humans, increased plasma quinolinic acid-to-kynurenic acid ratio levels have been associated with depressive behavior (Muller \& Schwarz 2007).

Another PGC-1a1-driven myokine is irisin, the secreted form of the muscle protein fibronectin type III domain-containing protein 5 (Bostrom et al. 2012). In C57BL/6 mice, VWR for 30 days increased PGC-1a1dependent Fndc5 and Bdnf mRNA expression specifically in the hippocampus (Wrann et al. 2013). The physiological role of irisin in exercise biology has been debated (Jedrychowski et al. 2015).

In C57BL/ 6 mice, VWR for 30 days increased cathepsin B plasma levels, suggesting it might be an exercise myokine, and increased hippocampal Cathepsin b mRNA expression (Moon et al. 2016). In this study, VWR had no effect on behavior in the sucrose consumption test, FST or open-field test in wild-type mice. However, the effects of 
VWR on memory and hippocampal neurogenesis appear to be dependent on Cathepsin B, as Cathepsin B-knockout mice failed to demonstrate these effects (Moon et al. 2016). Finally, changes in plasma Cathepsin B levels were increased in humans and rhesus monkeys following treadmill training and associated with improved cognitive skills in humans (Moon et al. 2016).

\section{Conclusions and perspectives}

The usage of VWR to model adaptations in humans during exercise training has generated substantial insight into molecular adaptations and brain circuitry involved in the beneficial effects of exercise on several aspects of behavior, including energy homeostasis, cognition and memory and stress susceptibility (Fig. 1). The recent introduction of innovative transgenic, pharmacogenetic and optogenetic techniques allows unprecedented analysis of the complexity of exercise biology at the molecular, cellular and neuronal circuit levels, which will lead to a new understanding of the beneficial adaptations underlying exercise training. An additional important challenge that remains is the ability to predict individual responses to different intensities of training, as exercise tailored to different stress sensitivity of individuals will promote compliance and success of therapeutic exercise programs. Newly discovered exercise myokines hold strong potential for therapeutic use, but need to be based on realistic expectations. For example, increases in plasma kynurenic acid were observed after a $150-\mathrm{km}$ road cycling time trial, but not after 100 drop jumps, indicating that kynurenic acid metabolism might not be affected by 5-km slow-pace run. Even more, comparison of exercise

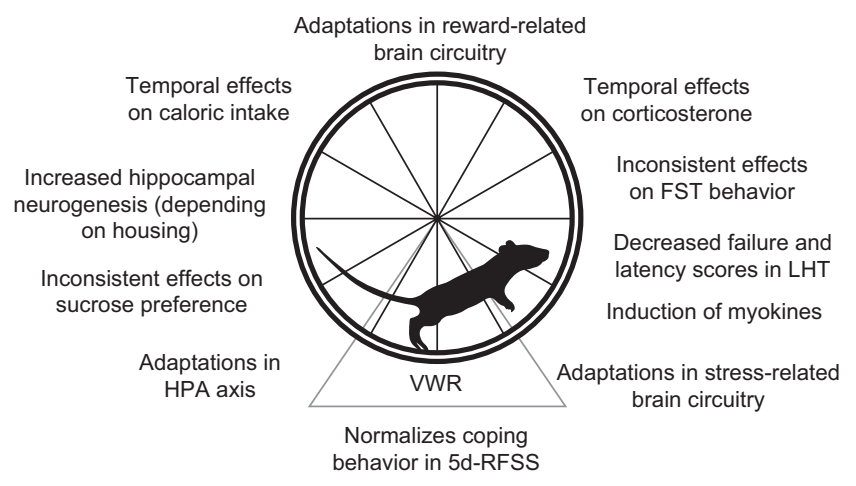

Figure 1

Summary of molecular and behavioral adaptations associated with altered stress-related behavior following VWR. 5d-RFSS, 5-day repeated forced-swim stress; FST, forced-swim test; LHT, learned helplessness test; HPA, hypothalamic-pituitary-adrenal. intensity and duration between rodents and humans, and even between mice and rats, remains a challenge.

CSDS, a widely used etiologically valid animal model of depression, is based on intermale dominance and only applied to males. As such, the insight generated by this model is always in the context of a male background. Fortunately, a recent report now also suggests that CSDS can be applied to induce depression-like behavior in female rodents (Iñiguez et al. 2017). Furthermore, early-life stress seems to affect males but not female rodents, suggesting susceptibility or resilience in either sex (Oomen et al. 2009). Given the sex-dependent vulnerability to stressrelated disorders, in a perfect world, an equal distribution in sexes should be investigated in preclinical models.

Animal models of aerobic exercise are used frequently; yet, animal models of anaerobic exercise are rare. For example, anaerobic resistance training or treadmill training in adult male Sprague-Dawley rats for 42-56 days revealed no effect of adult hippocampal neurogenesis, whereas VWR clearly did (Nokia et al. 2016). However, in women, both aerobic (running) and anaerobic (weight lifting) exercise for 56 days improved depression-related measures (Doyne et al. 1987). Given the popularity of anaerobic exercise, especially in younger generations, studies using valid animal models of anaerobic exercise will be a valuable addition to the field of exercise biology.

Several imaging techniques are now being utilized to visualize exercise training-induced in brain circuitry. For example, using MRI, it was demonstrated that $\mathrm{VO}_{2 \max }$ fitness or frequent walking is associated with greater hippocampal volume in humans (Erickson et al. 2009, 2010). Similarly, MRI demonstrated that 35-day VWR was associated with greater hippocampal volume in Flinders Sensitive Line rats (Sierakowiak et al. 2014). In mice, brain blood oxygen level-dependent (BOLD) MRI was used to examine functional changes in the brain induced by CUS or VWR, and several brain regions were identified as differentially activated (Huang et al. 2017). In human volunteers, resting state functional connectivity is different between young-adult endurance athletes and healthy controls and included enhanced connectivity between the frontoparietal network and frontal cortex (Raichlen et al. 2016). Another study conducted the Montreal Imaging Stress Task in lowly trained and highly trained young men, with or without aerobic exercise prior to the test and found no clear differences between training state, although acute exercise increased activity in the hippocampus and decreased activity in the prefrontal cortex (Zschucke et al. 2015). Many studies assess molecular adaptations after a 
given duration of VWR. However, several aspects of VWR, such as its effects on corticosterone dynamics or caloric intake, are temporal (Fediuc et al. 2006, Obici et al. 2015). Similarly, (behavioral) adaptations often only become visible after a minimal duration of VWR (Greenwood et al. 2005, Stranahan et al. 2006). Non-invasive in vivo imaging studies that visualize the temporal dynamics of the underlying central molecular adaptations are valuable (translational) tools that can improve our understanding how exercise duration and intensity affect individual responding to exercise. In summary, combining state-ofthe-art imaging techniques with classic molecular and genetic approaches will aid in the characterization of exercise training-induced adaptations in neurons of the stress- and reward-related brain circuitries. This insight may identify new targets for the development of muchneeded effective therapeutic treatments for stress-related disorders, including depression.

\section{Declaration of interest}

The author declares that there is no conflict of interest that could be perceived as prejudicing the impartiality of this review.

\section{Funding}

This work did not receive any specific grant from any funding agency in the public, commercial or not-for-profit sector.

\section{References}

Abbink MR, Naninck EFG, Lucassen PJ \& Korosi A 2017 Early-life stress diminishes the increase in neurogenesis after exerc ise in adult female mice. Hippocampus 27 839-844. (https://doi.org/10.1002/ hipo.22745)

Agudelo LZ, Femenia T, Orhan F, Porsmyr-Palmertz M, Goiny M, Martinez-Redondo V, Correia JC, Izadi M, Bhat M, SchuppeKoistinen I, et al. 2014 Skeletal muscle PGC-1alpha1 modulates kynurenine metabolism and mediates resilience to stress-induced depression. Cell 159 33-45. (https://doi.org/10.1016/j. cell.2014.07.051)

Alder J, Thakker-Varia S, Bangasser DA, Kuroiwa M, Plummer MR, Shors TJ \& Black IB 2003 Brain-derived neurotrophic factor-induced gene expression reveals novel actions of VGF in hippocampal synaptic plasticity. Journal of Neuroscience 23 10800-10808. (https:// doi.org/10.1002/hipo.20683)

Arnoldussen IA, Kiliaan AJ \& Gustafson DR 2014 Obesity and dementia adipokines interact with the brain. European Neuropsychopharmacology 24 1982-1999. (https://doi.org/10.1016/j.euroneuro.2014.03.002)

Asmundson GJ, Fetzner MG, Deboer LB, Powers MB, Otto MW \& Smits JA 2013 Let's get physical: a contemporary review of the anxiolytic effects of exercise for anxiety and its disorders. Depression and Anxiety 30 362-373. (https://doi.org/10.1002/da.22043)

Association AP 2013 Diagnostic and Statistical Manual of Mental Disorder (5th ed.). Washington, DC: American Psychiatric Association.

Belke TW 1997 Running and responding reinforced by the opportunity to run: effect of reinforcer duration. Journal of the Experimental
Analysis of Behavior 67 337-351. (https://doi.org/10.1901/ jeab.1997.67-337)

Belke TW \& Wagner JP 2005 The reinforcing property and the rewarding aftereffect of wheel running in rats: a combination of two paradigms. Behavioural Processes 68 165-172. (https://doi. org/10.1016/j.beproc.2004.12.006)

Belzung C \& Lemoine M 2011 Criteria of validity for animal models of psychiatric disorders: focus on anxiety disorders and depression. Biology of Mood and Anxiety Disorders 19. (https://doi. org/10.1186/2045-5380-1-9)

Berchtold NC, Chinn G, Chou M, Kesslak JP \& Cotman CW 2005 Exercise primes a molecular memory for brain-derived neurotrophic factor protein induction in the rat hippocampus. Neuroscience 133 853-861. (https://doi.org/10.1016/j. neuroscience.2005.03.026)

Berchtold NC, Castello N \& Cotman CW 2010 Exercise and timedependent benefits to learning and memory. Neuroscience $\mathbf{1 6 7}$ 588-597. (https://doi.org/10.1016/j.neuroscience.2010.02.050)

Berton O, McClung CA, Dileone RJ, Krishnan V, Renthal W, Russo SJ, Graham D, Tsankova NM, Bolanos CA, Rios M, et al. 2006 Essential role of BDNF in the mesolimbic dopamine pathway in social defeat stress. Science 311 864-868. (https://doi.org/10.1126/ science.1120972)

Bhatnagar S \& Dallman M 1998 Neuroanatomical basis for facilitation of hypothalamic-pituitary-adrenal responses to a novel stressor after chronic stress. Neuroscience 84 1025-1039. (https://doi.org/10.1016/ S0306-4522(97)00577-0)

Binder E, Droste SK, Ohl F \& Reul JM 2004 Regular voluntary exercise reduces anxiety-related behaviour and impulsiveness in mice. Behavioural Brain Research 155 197-206. (https://doi.org/10.1016/j. bbr.2004.04.017)

Bjornebekk A, Mathe AA \& Brene S 2005 The antidepressant effect of running is associated with increased hippocampal cell proliferation. International Journal of Neuropsychopharmacology 8 357-368. (https:// doi.org/10.1017/S1461145705005122)

Bjornebekk A, Mathe AA \& Brene S 2006 Running has differential effects on NPY, opiates, and cell proliferation in an animal model of depression and controls. Neuropsychopharmacology 31 256-264. (https://doi.org/10.1038/sj.npp.1300820)

Bjornebekk A, Mathe AA, Gruber SH \& Brene S 2008 Housing conditions modulate escitalopram effects on antidepressive-like behaviour and brain neurochemistry. International Journal of Neuropsychopharmacology 11 1135-1147. (https://doi.org/10.1017/ S1461145708008912)

Bjornebekk A, Mathe AA \& Brene S 2010 The antidepressant effects of running and escitalopram are associated with levels of hippocampal NPY and Y1 receptor but not cell proliferation in a rat model of depression. Hippocampus 20 820-828. (https://doi.org/10.1002/ hipo.20683)

Blumenthal JA, Smith PJ \& Hoffman BM 2012 Is exercise a viable treatment for depression? ACSM's Health and Fitness Journal 16 14-21. (https://doi.org/10.1249/01.FIT.0000416000.09526.eb)

Bosker FJ, Hartman CA, Nolte IM, Prins BP, Terpstra P, Posthuma D, van Veen T, Willemsen G, DeRijk RH, de Geus EJ, et al. 2011 Poor replication of candidate genes for major depressive disorder using genome-wide association data. Molecular Psychiatry 16 516-532. (https://doi.org/10.1038/mp.2010.38)

Bostrom P, Wu J, Jedrychowski MP, Korde A, Ye L, Lo JC, Rasbach KA, Bostrom EA, Choi JH, Long JZ, et al. 2012 A PGC1-alpha-dependent myokine that drives brown-fat-like development of white fat and thermogenesis. Nature $\mathbf{4 8 1}$ 463-468. (https://doi.org/10.1038/ nature10777)

Brocardo PS, Boehme F, Patten A, Cox A, Gil-Mohapel J \& Christie BR 2012 Anxiety- and depression-like behaviors are accompanied by an increase in oxidative stress in a rat model of fetal alcohol spectrum disorders: protective effects of voluntary physical exercise. 
Neuropharmacology 62 1607-1618. (https://doi.org/10.1016/j. neuropharm.2011.10.006)

Burghardt PR, Fulk LJ, Hand GA \& Wilson MA 2004 The effects of chronic treadmill and wheel running on behavior in rats. Brain Research 1019 84-96. (https://doi.org/10.1016/j.brainres.2004.05.086)

Campeau S, Nyhuis TJ, Sasse SK, Kryskow EM, Herlihy L, Masini CV, Babb JA, Greenwood BN, Fleshner M \& Day HE 2010 Hypothalamic pituitary adrenal axis responses to low-intensity stressors are reduced after voluntary wheel running in rats. Journal of Neuroendocrinology 22 872-888. (https://doi.org/10.1111/j.1365-2826.2010.02007.x)

Carek PJ, Laibstain SE \& Carek SM 2011 Exercise for the treatment of depression and anxiety. International Journal of Psychiatry in Medicine 41 15-28. (https://doi.org/10.2190/PM.41.1.c)

Chadman KK, Yang M \& Crawley JN 2009 Criteria for validating mouse models of psychiatric diseases. American Journal of Medical Genetics Part B: Neuropsychiatric Genetics 150B 1-11. (https://doi.org/10.1002/ ajmg.b.30777)

Charney DS 2004 Psychobiological mechanisms of resilience and vulnerability: implications for successful adaptation to extreme stress. American Journal of Psychiatry 161 195-216. (https://doi. org/10.1176/appi.ajp.161.2.195)

Chen C, Nakagawa S, Kitaichi Y, An Y, Omiya Y, Song N, Koga M, Kato A, Inoue T \& Kusumi I 2016 The role of medial prefrontal corticosterone and dopamine in the antidepressant-like effect of exercise. Psychoneuroendocrinology 69 1-9. (https://doi.org/10.1016/j. psyneuen.2016.03.008)

Cooper C, Moon HY \& van Praag H 2017 On the run for hippocampal plasticity. Cold Spring Harbor Perspectives in Medicine. Epub. (https:// doi.org/10.1101/cshperspect.a029736)

Cotman CW \& Berchtold NC 2002 Exercise: a behavioral intervention to enhance brain health and plasticity. Trends in Neurosciences $\mathbf{2 5}$ 295-301. (https://doi.org/10.1016/S0166-2236(02)02143-4)

Cunha MP, Oliveira A, Pazini FL, Machado DG, Bettio LE, Budni J, Aguiar AS Jr, Martins DF, Santos AR \& Rodrigues AL 2013 The antidepressant-like effect of physical activity on a voluntary running wheel. Medicine and Science in Sports and Exercise 45 851-859. (https://doi.org/10.1249/MSS.0b013e31827b23e6)

de Kloet ER \& Molendijk ML 2016 Coping with the forced swim stressor: towards understanding an adaptive mechanism. Neural Plasticity 2016 6503162. (https://doi.org/10.1038/nrn1683)

de Kloet ER, Joels M \& Holsboer F 2005 Stress and the brain: from adaptation to disease. Nature Reviews Neuroscience 6 463-475. (https://doi.org/10.1038/nrn1683)

Delcourte S, Dkhissi-Benyahya O, Cooper H \& Haddjeri N 2017 Stress models of depression: a question of bad timing. eNeuro 4. (https:// doi.org/10.1523/ENEURO.0045-17.2017)

Dimeo F, Bauer M, Varahram I, Proest G \& Halter U 2001 Benefits from aerobic exercise in patients with major depression: a pilot study. British Journal of Sports Medicine 35 114-117. (https://doi. org/10.1136/bjsm.35.2.114)

Dishman RK, Renner KJ, Youngstedt SD, Reigle TG, Bunnell BN, Burke KA, Yoo HS, Mougey EH \& Meyerhoff JL 1997 Activity wheel running reduces escape latency and alters brain monoamine levels after footshock. Brain Research Bulletin 42 399-406. (https://doi. org/10.1016/S0361-9230(96)00329-2)

Dishman RK, Berthoud HR, Booth FW, Cotman CW, Edgerton VR, Fleshner MR, Gandevia SC, Gomez-Pinilla F, Greenwood BN, Hillman $\mathrm{CH}$, et al. 2006 Neurobiology of exercise. Obesity $\mathbf{1 4}$ 345-356. (https://doi.org/10.1038/oby.2006.46)

Doyne EJ, Ossip-Klein DJ, Bowman ED, Osborn KM, McDougallWilson IB \& Neimeyer RA 1987 Running versus weight lifting in the treatment of depression. Journal of Consulting and Clinical Psychology 55 748-754. (https://doi.org/10.1037/0022006X.55.5.748)

Droste SK, Gesing A, Ulbricht S, Muller MB, Linthorst AC \& Reul JM 2003 Effects of long-term voluntary exercise on the mouse hypothalamic-pituitary-adrenocortical axis. Endocrinology 144 3012-3023. (https://doi.org/10.1210/en.2003-0097)

Droste SK, Schweizer MC, Ulbricht S \& Reul JM 2006 Long-term voluntary exercise and the mouse hypothalamic-pituitaryadrenocortical axis: impact of concurrent treatment with the antidepressant drug tianeptine. Journal of Neuroendocrinology $\mathbf{1 8}$ 915-925. (https://doi.org/10.1111/j.1365-2826.2006.01489.x)

Droste SK, Chandramohan Y, Hill LE, Linthorst AC \& Reul JM 2007 Voluntary exercise impacts on the rat hypothalamic-pituitaryadrenocortical axis mainly at the adrenal level. Neuroendocrinology $\mathbf{8 6}$ 26-37. (https://doi.org/10.1159/000104770)

Dubreucq S, Durand A, Matias I, Benard G, Richard E, Soria-Gomez E, Glangetas C, Groc L, Wadleigh A, Massa F, et al. 2013 Ventral tegmental area cannabinoid type-1 receptors control voluntary exercise performance. Biological Psychiatry 73 895-903. (https://doi. org/10.1016/j.biopsych.2012.10.025)

Duman RS \& Monteggia LM 2006 A neurotrophic model for stressrelated mood disorders. Biological Psychiatry 59 1116-1127. (https:// doi.org/10.1016/j.biopsych.2006.02.013)

Duman CH, Schlesinger L, Russell DS \& Duman RS 2008 Voluntary exercise produces antidepressant and anxiolytic behavioral effects in mice. Brain Research 1199 148-158. (https://doi.org/10.1016/j. brainres.2007.12.047)

Duman CH, Schlesinger L, Terwilliger R, Russell DS, Newton SS \& Duman RS 2009 Peripheral insulin-like growth factor-I produces antidepressant-like behavior and contributes to the effect of exercise. Behavioural Brain Research 198 366-371. (https://doi.org/10.1016/j. bbr.2008.11.016)

Duzel E, van Praag H \& Sendtner M 2016 Can physical exercise in old age improve memory and hippocampal function? Brain 139 662-673. (https://doi.org/10.1093/brain/awv407)

Eisch AJ, Bolanos CA, de Wit J, Simonak RD, Pudiak CM, Barrot M, Verhaagen J \& Nestler EJ 2003 Brain-derived neurotrophic factor in the ventral midbrain-nucleus accumbens pathway: a role in depression. Biological Psychiatry 54 994-1005. (https://doi. org/10.1016/j.biopsych.2003.08.003)

Eldomiaty MA, Almasry SM, Desouky MK \& Algaidi SA 2017 Voluntary running improves depressive behaviours and the structure of the hippocampus in rats: a possible impact of myokines. Brain Research 1657 29-42. (https://doi.org/10.1016/j.brainres.2016.12.001)

Erickson KI, Prakash RS, Voss MW, Chaddock L, Hu L, Morris KS, White SM, Wojcicki TR, McAuley E \& Kramer AF 2009 Aerobic fitness is associated with hippocampal volume in elderly humans. Hippocampus 19 1030-1039. (https://doi.org/10.1002/hipo.20547)

Erickson KI, Raji CA, Lopez OL, Becker JT, Rosano C, Newman AB, Gach HM, Thompson PM, Ho AJ \& Kuller LH 2010 Physical activity predicts gray matter volume in late adulthood: the Cardiovascular Health Study. Neurology 75 1415-1422. (https://doi.org/10.1212/ WNL.0b013e3181f88359)

Fabel K, Fabel K, Tam B, Kaufer D, Baiker A, Simmons N, Kuo CJ \& Palmer TD 2003 VEGF is necessary for exercise-induced adult hippocampal neurogenesis. European Journal of Neuroscience $\mathbf{1 8}$ 2803-2812. (https://doi.org/10.1111/j.1460-9568.2003.03041.x)

Feder A, Nestler EJ \& Charney DS 2009 Psychobiology and molecular genetics of resilience. Nature Reviews Neuroscience 10 446-457. (https://doi.org/10.1038/nrn2649)

Fediuc S, Campbell JE \& Riddell MC 2006 Effect of voluntary wheel running on circadian corticosterone release and on HPA axis responsiveness to restraint stress in Sprague-Dawley rats. Journal of Applied Physiology 100 1867-1875. (https://doi.org/10.1152/ japplphysiol.01416.2005)

Fernandes MF, Matthys D, Hryhorczuk C, Sharma S, Mogra S, Alquier T \& Fulton S 2015 Leptin suppresses the rewarding effects of running via STAT3 signaling in dopamine neurons. Cell Metabolism 22 741-749. (https://doi.org/10.1016/j. cmet.2015.08.003) 
Foldi CJ, Milton LK \& Oldfield BJ 2017 The role of mesolimbic reward neurocircuitry in prevention and rescue of the activity-based anorexia (ABA) phenotype in rats. Neuropsychopharmacology 42 2292-2300. (https://doi.org/10.1038/npp.2017.63)

Fox KR 1999 The influence of physical activity on mental well-being. Public Health Nutrition 2 411-418.

Fuss J \& Gass P 2010 Endocannabinoids and voluntary activity in mice: runner's high and long-term consequences in emotional behaviors. Experimental Neurology 224 103-105. (https://doi.org/10.1016/j. expneurol.2010.03.016)

Fuss J, Ben Abdallah NM, Vogt MA, Touma C, Pacifici PG, Palme R, Witzemann V, Hellweg R \& Gass P 2010 Voluntary exercise induces anxiety-like behavior in adult C57BL/6J mice correlating with hippocampal neurogenesis. Hippocampus 20 364-376. (https://doi. org/10.1002/hipo.20634)

Garland T Jr, Schutz H, Chappell MA, Keeney BK, Meek TH, Copes LE, Acosta W, Drenowatz C, Maciel RC, van Dijk G, et al. 2011 The biological control of voluntary exercise, spontaneous physical activity and daily energy expenditure in relation to obesity: human and rodent perspectives. Journal of Experimental Biology 214 206-229. (https://doi.org/10.1242/jeb.048397)

Girard I \& Garland T Jr 2002 Plasma corticosterone response to acute and chronic voluntary exercise in female house mice. Journal of Applied Physiology 92 1553-1561. (https://doi.org/10.1152/ japplphysiol.00465.2001)

Greenberg PE, Kessler RC, Birnbaum HG, Leong SA, Lowe SW, Berglund PA \& Corey-Lisle PK 2003 The economic burden of depression in the United States: how did it change between 1990 and 2000? Journal of Clinical Psychiatry 64 1465-1475. (https://doi. org/10.4088/JCP.v64n1211)

Greenwood BN \& Fleshner M 2008 Exercise, learned helplessness, and the stress-resistant brain. NeuroMolecular Medicine 10 81-98. (https:// doi.org/10.1007/s12017-008-8029-y)

Greenwood BN \& Fleshner M 2011 Exercise, stress resistance, and central serotonergic systems. Exercise and Sport Sciences Reviews 39 140-149. (https://doi.org/10.1097/JES.0b013e31821f7e45)

Greenwood BN, Foley TE, Day HE, Campisi J, Hammack SH, Campeau S, Maier SF \& Fleshner M 2003 Freewheel running prevents learned helplessness/behavioral depression: role of dorsal raphe serotonergic neurons. Journal of Neuroscience 23 2889-2898.

Greenwood BN, Foley TE, Burhans D, Maier SF \& Fleshner M 2005 The consequences of uncontrollable stress are sensitive to duration of prior wheel running. Brain Research 1033 164-178. (https://doi. org/10.1016/j.brainres.2004.11.037)

Greenwood BN, Foley TE, Le TV, Strong PV, Loughridge AB, Day HE \& Fleshner M 2011 Long-term voluntary wheel running is rewarding and produces plasticity in the mesolimbic reward pathway. Behavioural Brain Research 217 354-362. (https://doi.org/10.1016/j. bbr.2010.11.005)

Grippo AJ, Beltz TG \& Johnson AK 2003 Behavioral and cardiovascular changes in the chronic mild stress model of depression. Physiology and Behavior 78 703-710. (https://doi.org/10.1016/S00319384(03)00050-7)

Hahm S, Mizuno TM, Wu TJ, Wisor JP, Priest CA, Kozak CA, Boozer CN, Peng B, McEvoy RC, Good P, et al. 1999 Targeted deletion of the Vgf gene indicates that the encoded secretory peptide precursor plays a novel role in the regulation of energy balance. Neuron 23 537-548. (https://doi.org/10.1016/S08966273(00)80806-5)

Hawkins J, Hicks RA, Phillips N \& Moore JD 1978 Swimming rats and human depression. Nature 274 512-513. (https://doi. org/10.1038/274512a0)

Hoge EA, Austin ED \& Pollack MH 2007 Resilience: research evidence and conceptual considerations for posttraumatic stress disorder. Depression and Anxiety 24 139-152. (https://doi.org/10.1002/da.20175)
Hope BT, Nye HE, Kelz MB, Self DW, Iadarola MJ, Nakabeppu Y, Duman RS \& Nestler EJ 1994 Induction of a long-lasting AP-1 complex composed of altered Fos-like proteins in brain by chronic cocaine and other chronic treatments. Neuron 13 1235-1244. (https://doi.org/10.1016/0896-6273(94)90061-2)

Hsu YW, Wang SD, Wang S, Morton G, Zariwala HA, de la Iglesia HO \& Turner EE 2014 Role of the dorsal medial habenula in the regulation of voluntary activity, motor function, hedonic state, and primary reinforcement. Journal of Neuroscience 34 11366-11384. (https://doi. org/10.1523/JNEUROSCI.1861-14.2014)

Huang P, Dong Z, Huang W, Zhou C, Zhong W, Hu P, Wen G, Sun X, Hua H, Cao H, et al. 2017 Voluntary wheel running ameliorates depression-like behaviors and brain blood oxygen level-dependent signals in chronic unpredictable mild stress mice. Behavioural Brain Research 330 17-24. (https://doi.org/10.1016/j.bbr.2017.05.032)

Hunsberger JG, Newton SS, Bennett AH, Duman CH, Russell DS, Salton SR \& Duman RS 2007 Antidepressant actions of the exerciseregulated gene VGF. Nature Medicine 13 1476-1482. (https://doi. org/10.1038/nm1669)

Iñiguez SD, Flores-Ramirez FJ, Riggs LM, Alipio JB, Garcia I, Hernandez MA, Sanchez DO, Lobo MK, Serrano PA, Braren SH, et al. 2017 Vicarious social defeat stress induces depression-related outcomes in female mice. Biological Psychiatry 83 9-17. (https://doi. org/10.1016/j.biopsych.2017.07.014)

Iversen IH 1993 Techniques for establishing schedules with wheel running as reinforcement in rats. Journal of the Experimental Analysis of Behavior 60 219-238. (https://doi.org/10.1901/jeab.1993.60-219)

Jedrychowski MP, Wrann CD, Paulo JA, Gerber KK, Szpyt J, Robinson MM, Nair KS, Gygi SP \& Spiegelman BM 2015 Detection and quantitation of circulating human irisin by tandem mass spectrometry. Cell Metabolism 22 734-740. (https://doi.org/10.1016/j. cmet.2015.08.001)

Jiang C, Lin WJ, Sadahiro M, Labonte B, Menard C, Pfau ML, Tamminga CA, Turecki G, Nestler EJ, Russo SJ, et al. 2017 VGF function in depression and antidepressant efficacy. Molecular Psychiatry Epub. (https://doi.org/10.1038/mp.2017.233)

Joels M, Karst H, Krugers HJ \& Lucassen PJ 2007 Chronic stress: implications for neuronal morphology, function and neurogenesis. Frontiers in Neuroendocrinology 28 72-96. (https://doi.org/10.1016/j. yfrne.2007.04.001)

Josefsson T, Lindwall M \& Archer T 2014 Physical exercise intervention in depressive disorders: meta-analysis and systematic review. Scandinavian Journal of Medicine and Science in Sports 24 259-272. (https://doi.org/10.1111/sms.12050)

Kessler RC, Berglund P, Demler O, Jin R, Merikangas KR \& Walters EE 2005 Lifetime prevalence and age-of-onset distributions of DSM-IV disorders in the National Comorbidity Survey Replication. Archives of General Psychiatry 62 593-602. (https://doi.org/10.1001/ archpsyc.62.6.593)

Kessler RC, Amminger GP, Aguilar-Gaxiola S, Alonso J, Lee S \& Ustun TB 2007 Age of onset of mental disorders: a review of recent literature. Current Opinion in Psychiatry 20 359-364. (https://doi.org/10.1097/ YCO.0b013e32816ebc8c)

Khawaja X, Xu J, Liang JJ \& Barrett JE 2004 Proteomic analysis of protein changes developing in rat hippocampus after chronic antidepressant treatment: implications for depressive disorders and future therapies. Journal of Neuroscience Research 75 451-460. (https:// doi.org/10.1002/jnr.10869)

Koolhaas JM, De Boer SF, De Rutter AJ, Meerlo P \& Sgoifo A 1997 Social stress in rats and mice. Acta Physiologica Scandinavica Supplementum 640 69-72.

Korosi A, Naninck EF, Oomen CA, Schouten M, Krugers H, Fitzsimons C \& Lucassen PJ 2012 Early-life stress mediated modulation of adult neurogenesis and behavior. Behavioural Brain Research 227 400-409. (https://doi.org/10.1016/j.bbr.2011.07.037) 
Krishnan V \& Nestler EJ 2008 The molecular neurobiology of depression. Nature 455 894-902. (https://doi.org/10.1038/ nature07455)

Krishnan V, Han MH, Graham DL, Berton O, Renthal W, Russo SJ, Laplant Q, Graham A, Lutter M, Lagace DC, et al. 2007 Molecular adaptations underlying susceptibility and resistance to social defeat in brain reward regions. Cell 131 391-404. (https://doi.org/10.1016/j. cell.2007.09.018)

Krogh J, Nordentoft M, Sterne JA \& Lawlor DA 2011 The effect of exercise in clinically depressed adults: systematic review and metaanalysis of randomized controlled trials. Journal of Clinical Psychiatry 72 529-538. (https://doi.org/10.4088/JCP.08r04913blu)

Krugers HJ, Arp JM, Xiong H, Kanatsou S, Lesuis SL, Korosi A, Joels M \& Lucassen PJ 2017 Early life adversity: lasting consequences for emotional learning. Neurobiology of Stress 6 14-21. (https://doi. org/10.1016/j.ynstr.2016.11.005)

Kubota N, Yano W, Kubota T, Yamauchi T, Itoh S, Kumagai H, Kozono H, Takamoto I, Okamoto S, Shiuchi T, et al. 2007 Adiponectin stimulates AMP-activated protein kinase in the hypothalamus and increases food intake. Cell Metabolism 6 55-68. (https://doi.org/10.1016/j.cmet.2007.06.003)

Kudryavtseva NN, Bakshtanovskaya IV \& Koryakina LA 1991 Social model of depression in mice of C57BL/6J strain. Pharmacology Biochemistry and Behavior 38 315-320. (https://doi.org/10.1016/00913057(91)90284-9)

Lai SM, Studenski S, Richards L, Perera S, Reker D, Rigler S \& Duncan PW 2006 Therapeutic exercise and depressive symptoms after stroke. Journal of the American Geriatrics Society 54 240-247. (https://doi.org/10.1111/j.1532-5415.2006.00573.x)

Lancel M, Droste SK, Sommer S \& Reul JM 2003 Influence of regular voluntary exercise on spontaneous and social stress-affected sleep in mice. European Journal of Neuroscience 17 2171-2179. (https://doi. org/10.1046/j.1460-9568.2003.02658.x)

Lapmanee S, Charoenphandhu J, Teerapornpuntakit J, Krishnamra N \& Charoenphandhu N 2017 Agomelatine, venlafaxine, and running exercise effectively prevent anxiety- and depression-like behaviors and memory impairment in restraint stressed rats. PLoS ONE 12 e0187671. (https://doi.org/10.1371/journal. pone.0187671)

Lawlor DA \& Hopker SW 2001 The effectiveness of exercise as an intervention in the management of depression: systematic review and meta-regression analysis of randomised controlled trials. $B M J$ 322 763-767. (https://doi.org/10.1136/bmj.322.7289.763)

Lehmann ML \& Herkenham M 2011 Environmental enrichment confers stress resiliency to social defeat through an infralimbic cortex-dependent neuroanatomical pathway. Journal of Neuroscience 31 6159-6173. (https://doi.org/10.1523/ JNEUROSCI.0577-11.2011)

Lett BT, Grant VL, Byrne MJ \& Koh MT 2000 Pairings of a distinctive chamber with the aftereffect of wheel running produce conditioned place preference. Appetite 34 87-94. (https://doi.org/10.1006/ appe.1999.0274)

Lewis GD, Farrell L, Wood MJ, Martinovic M, Arany Z, Rowe GC, Souza A, Cheng S, McCabe EL, Yang E, et al. 2010 Metabolic signatures of exercise in human plasma. Science Translational Medicine 2 33ra37. (https://doi.org/10.1126/ scitranslmed.3001006)

Lightfoot JT, Turner MJ, Daves M, Vordermark A \& Kleeberger SR 2004 Genetic influence on daily wheel running activity level. Physiological Genomics 19 270-276. (https://doi.org/10.1152/ physiolgenomics.00125.2004)

Marais L, Stein DJ \& Daniels WM 2009 Exercise increases BDNF levels in the striatum and decreases depressive-like behavior in chronically stressed rats. Metabolic Brain Disease 24 587-597. (https://doi. org/10.1007/s11011-009-9157-2)
Markou A, Chiamulera C, Geyer MA, Tricklebank M \& Steckler T 2009 Removing obstacles in neuroscience drug discovery: the future path for animal models. Neuropsychopharmacology 34 74-89. (https://doi. org/10.1038/npp.2008.173)

McClung CA \& Nestler EJ 2003 Regulation of gene expression and cocaine reward by CREB and DeltaFosB. Nature Neuroscience $\mathbf{6}$ 1208-1215. (https://doi.org/10.1038/nn1143)

McEwen BS 2001 Plasticity of the hippocampus: adaptation to chronic stress and allostatic load. Annals of the New York Academy of Sciences 933 265-277. (https://doi.org/10.1111/j.1749-6632.2001.tb05830.x)

McEwen BS 2007 Physiology and neurobiology of stress and adaptation: central role of the brain. Physiological Reviews 87 873-904. (https:// doi.org/10.1152/physrev.00041.2006)

Meaney MJ 2001 Maternal care, gene expression, and the transmission of individual differences in stress reactivity across generations. Annual Review of Neuroscience 24 1161-1192. (https://doi. org/10.1146/annurev.neuro.24.1.1161)

Meijer JH \& Robbers Y 2014 Wheel running in the wild. Proceedings: Biological Sciences 281. (https://doi.org/10.1098/rspb.2014.0210)

Melas PA, Lennartsson A, Vakifahmetoglu-Norberg H, Wei Y, Aberg E, Werme M, Rogdaki M, Mannervik M, Wegener G, Brene S, et al. 2013 Allele-specific programming of Npy and epigenetic effects of physical activity in a genetic model of depression. Translational Psychiatry 3 e255. (https://doi.org/10.1038/tp.2013.31)

Millischer V, Erhardt S, Ekblom O, Forsell Y \& Lavebratt C 2017 Twelveweek physical exercise does not have a long-lasting effect on kynurenines in plasma of depressed patients. Neuropsychiatric Disease and Treatment 13 967-972. (https://doi.org/10.2147/NDT.S131746)

Molendijk ML \& de Kloet ER 2015 Immobility in the forced swim test is adaptive and does not reflect depression. Psychoneuroendocrinology 62 389-391. (https://doi.org/10.1016/j.psyneuen.2015.08.028)

Moon HY, Becke A, Berron D, Becker B, Sah N, Benoni G, Janke E, Lubejko ST, Greig NH, Mattison JA, et al. 2016 Running-induced systemic cathepsin B secretion is associated with memory function. Cell Metabolism 24 332-340. (https://doi.org/10.1016/j. cmet.2016.05.025)

Morgan WP 1969 A pilot investigation of physical working capacity in depressed and nondepressed psychiatric males. Research Quarterly $\mathbf{4 0}$ 859-861.

Morton GJ, Meek TH \& Schwartz MW 2014 Neurobiology of food intake in health and disease. Nature Reviews Neuroscience 15 367-378. (https://doi.org/10.1038/nrn3745)

Mul JD, Zheng J \& Goodyear LJ 2016 Validity assessment of 5 day repeated forced-swim stress to model human depression in youngadult C57BL/6J and BALB/cJ mice. eNeuro 3. (https://doi. org/10.1523/ENEURO.0201-16.2016)

Muller MB \& Holsboer F 2006 Mice with mutations in the HPA-system as models for symptoms of depression. Biological Psychiatry 59 1104-1115. (https://doi.org/10.1016/j.biopsych.2006.02.008)

Muller N \& Schwarz MJ 2007 The immune-mediated alteration of serotonin and glutamate: towards an integrated view of depression. Molecular Psychiatry 12 988-1000. (https://doi.org/10.1038/sj. mp.4002006)

Neeper SA, Gomez-Pinilla F, Choi J \& Cotman C 1995 Exercise and brain neurotrophins. Nature 373 109. (https://doi.org/10.1038/373109a0)

Neeper SA, Gomez-Pinilla F, Choi J \& Cotman CW 1996 Physical activity increases mRNA for brain-derived neurotrophic factor and nerve growth factor in rat brain. Brain Research 726 49-56. (https:// doi.org/10.1016/0006-8993(96)00273-9)

Nestler EJ 2015 FosB: a transcriptional regulator of stress and antidepressant responses. European Journal of Pharmacology $\mathbf{7 5 3}$ 66-72. (https://doi.org/10.1016/j.ejphar.2014.10.034)

Nestler EJ \& Hyman SE 2010 Animal models of neuropsychiatric disorders. Nature Neuroscience 13 1161-1169. (https://doi. org/10.1038/nn.2647) 
Nguemeni C, McDonald MW, Jeffers MS, Livingston-Thomas J, Lagace D \& Corbett D 2017 Short- and long-term exposure to low and high dose running produce differential effects on hippocampal neurogenesis. Neuroscience 369 202-211. (https://doi.org/10.1016/j. neuroscience.2017.11.026)

Nicolas S, Veyssiere J, Gandin C, Zsurger N, Pietri M, Heurteaux C, Glaichenhaus N, Petit-Paitel A \& Chabry J 2015 Neurogenesisindependent antidepressant-like effects of enriched environment is dependent on adiponectin. Psychoneuroendocrinology 57 72-83. (https://doi.org/10.1016/j.psyneuen.2015.03.017)

Nishijima T, Kawakami M \& Kita I 2013a Long-term exercise is a potent trigger for DeltaFosB induction in the hippocampus along the dorsoventral axis. PLOS ONE 8 e81245. (https://doi.org/10.1371/journal. pone.0081245)

Nishijima T, Llorens-Martin M, Tejeda GS, Inoue K, Yamamura Y, Soya H, Trejo JL \& Torres-Aleman I 2013b Cessation of voluntary wheel running increases anxiety-like behavior and impairs adult hippocampal neurogenesis in mice. Behavioural Brain Research $\mathbf{2 4 5}$ 34-41. (https://doi.org/10.1016/j.bbr.2013.02.009)

Nokia MS, Lensu S, Ahtiainen JP, Johansson PP, Koch LG, Britton SL \& Kainulainen H 2016 Physical exercise increases adult hippocampal neurogenesis in male rats provided it is aerobic and sustained. Journal of Physiology 594 1855-1873. (https://doi.org/10.1113/JP271552)

North TC, McCullagh P \& Tran ZV 1990 Effect of exercise on depression. Exercise and Sport Sciences Reviews 18 379-415. (https://doi. org/10.1249/00003677-199001000-00016)

Novak CM, Burghardt PR \& Levine JA 2012 The use of a running wheel to measure activity in rodents: relationship to energy balance, general activity, and reward. Neuroscience and Biobehavioral Reviews 36 1001-1014. (https://doi.org/10.1016/j. neubiorev.2011.12.012)

Obici S, Magrisso IJ, Ghazarian AS, Shirazian A, Miller JR, Loyd CM, Begg DP, Krawczewski Carhuatanta KA, Haas MK, Davis JF, et al. 2015 Moderate voluntary exercise attenuates the metabolic syndrome in melanocortin-4 receptor-deficient rats showing central dopaminergic dysregulation. Molecular Metabolism 4 692-705. (https://doi.org/10.1016/j.molmet.2015.07.003)

Oomen CA, Girardi CE, Cahyadi R, Verbeek EC, Krugers H, Joels M \& Lucassen PJ 2009 Opposite effects of early maternal deprivation on neurogenesis in male versus female rats. PLOS ONE 4 e3675. (https:// doi.org/10.1371/journal.pone.0003675)

Otsuka A, Shiuchi T, Chikahisa S, Shimizu N \& Sei H 2015 Voluntary exercise and increased food intake after mild chronic stress improve social avoidance behavior in mice. Physiology and Behavior 151 264-271. (https://doi.org/10.1016/j.physbeh.2015.07.024)

Patterson CM \& Levin BE 2008 Role of exercise in the central regulation of energy homeostasis and in the prevention of obesity. Neuroendocrinology 87 65-70. (https://doi.org/10.1159/000100982)

Perraton LG, Kumar S \& Machotka Z 2010 Exercise parameters in the treatment of clinical depression: a systematic review of randomized controlled trials. Journal of Evaluation in Clinical Practice 16 597-604. (https://doi.org/10.1111/j.1365-2753.2009.01188.x)

Pittenger C \& Duman RS 2008 Stress, depression, and neuroplasticity: a convergence of mechanisms. Neuropsychopharmacology 33 88-109. (https://doi.org/10.1038/sj.npp.1301574)

Porsolt RD, Bertin A \& Jalfre M 1977a Behavioral despair in mice: a primary screening test for antidepressants. Archives Internationales De Pharmacodynamie Et De Therapie 229 327-336.

Porsolt RD, Le Pichon M \& Jalfre M 1977b Depression: a new animal model sensitive to antidepressant treatments. Nature 266 730-732. (https://doi.org/10.1038/266730a0)

Porsolt RD, Anton G, Blavet N \& Jalfre M 1978a Behavioural despair in rats: a new model sensitive to antidepressant treatments. European Journal of Pharmacology 47 379-391. (https://doi.org/10.1016/00142999(78)90118-8)
Porsolt RD, Bertin A \& Jalfre M 1978b 'Behavioural despair' in rats and mice: strain differences and the effects of imipramine. European Journal of Pharmacology 51 291-294. (https://doi.org/10.1016/00142999(78)90414-4)

Pothion S, Bizot JC, Trovero F \& Belzung C 2004 Strain differences in sucrose preference and in the consequences of unpredictable chronic mild stress. Behavioural Brain Research 155 135-146. (https://doi. org/10.1016/j.bbr.2004.04.008)

Premack D 1962 Reversibility of the reinforcement relation. Science $\mathbf{1 3 6}$ 255-257. (https://doi.org/10.1126/science.136.3512.255)

Raichlen DA, Bharadwaj PK, Fitzhugh MC, Haws KA, Torre GA, Trouard TP \& Alexander GE 2016 Differences in resting state functional connectivity between young adult endurance athletes and healthy controls. Frontiers in Human Neuroscience 10 610. (https:// doi.org/10.3389/fnhum.2016.00610)

Ramirez S, Liu X, MacDonald CJ, Moffa A, Zhou J, Redondo RL \& Tonegawa S 2015 Activating positive memory engrams suppresses depression-like behaviour. Nature 522 335-339. (https://doi. org/10.1038/nature14514)

Reul JMHM \& Droste SK 2005 The hypothalamic-pitiutary-adrenal axis as a dynamically organized system: lessons from exercising mice. In Handbook of Stress and the Brain - Part 1: The Neurobiology of Stress, pp 95-112. Eds T Steckler, NH Kalin \& JMHM Reul. Amsterdam: Elsevier.

Reul JM, Collins A, Saliba RS, Mifsud KR, Carter SD, GutierrezMecinas M, Qian X \& Linthorst AC 2015 Glucocorticoids, epigenetic control and stress resilience. Neurobiology of Stress 1 44-59. (https:// doi.org/10.1016/j.ynstr.2014.10.001)

Rhodes JS, Garland T Jr \& Gammie SC 2003 Patterns of brain activity associated with variation in voluntary wheel-running behavior. Behavioral Neuroscience 117 1243-1256. (https://doi. org/10.1037/0735-7044.117.6.1243)

Richter SH, Gass P \& Fuss J 2014 Resting is rusting: a critical view on rodent wheel-running behavior. Neuroscientist 20 313-325. (https:// doi.org/10.1177/1073858413516798)

Roberts MD, Gilpin L, Parker KE, Childs TE, Will MJ \& Booth FW 2012 Dopamine D1 receptor modulation in nucleus accumbens lowers voluntary wheel running in rats bred to run high distances. Physiology and Behavior 105 661-668. (https://doi.org/10.1016/j. physbeh.2011.09.024)

Robison AJ \& Nestler EJ 2011 Transcriptional and epigenetic mechanisms of addiction. Nature Reviews Neuroscience 12 623-637. (https://doi.org/10.1038/nrn3111)

Rossi S, De Chiara V, Musella A, Kusayanagi H, Mataluni G, Bernardi G, Usiello A \& Centonze D 2008 Chronic psychoemotional stress impairs cannabinoid-receptor-mediated control of GABA transmission in the striatum. Journal of Neuroscience 28 7284-7292. (https://doi.org/10.1523/JNEUROSCI.5346-07.2008)

Rowe GC, Safdar A \& Arany Z 2014 Running forward: new frontiers in endurance exercise biology. Circulation 129 798-810. (https://doi. org/10.1161/CIRCULATIONAHA.113.001590)

Ruegsegger GN \& Booth FW 2017 Running from disease: molecular mechanisms associating dopamine and leptin signaling in the brain with physical inactivity, obesity, and type 2 diabetes. Frontiers in Endocrinology 8 109. (https://doi.org/10.3389/fendo.2017.00109)

Ruegsegger GN, Toedebusch RG, Childs TE, Grigsby KB \& Booth FW 2017 Loss of Cdk5 function in the nucleus accumbens decreases wheel running and may mediate age-related declines in voluntary physical activity. Journal of Physiology 595 363-384. (https://doi. org/10.1113/JP272489)

Russo SJ \& Nestler EJ 2013 The brain reward circuitry in mood disorders. Nature Reviews Neuroscience 14 609-625. (https://doi.org/10.1038/ nrn3381)

Russo SJ, Murrough JW, Han MH, Charney DS \& Nestler EJ 2012 Neurobiology of resilience. Nature Neuroscience 15 1475-1484. (https://doi.org/10.1038/nn.3234) 
Ryan KK, Mul JD, Clemmensen C, Egan AE, Begg DP, Halcomb K, Seeley RJ, Herman JP \& Ulrich-Lai YM 2014 Loss of melanocortin-4 receptor function attenuates HPA responses to psychological stress. Psychoneuroendocrinology 42 98-105. (https://doi.org/10.1016/j. psyneuen.2014.01.010)

Rygula R, Abumaria N, Flugge G, Fuchs E, Ruther E \& HavemannReinecke U 2005 Anhedonia and motivational deficits in rats: impact of chronic social stress. Behavioural Brain Research 162 127-134. (https://doi.org/10.1016/j.bbr.2005.03.009)

Rygula R, Abumaria N, Domenici E, Hiemke C \& Fuchs E 2006 Effects of fluoxetine on behavioral deficits evoked by chronic social stress in rats. Behavioural Brain Research 174 188-192. (https://doi. org/10.1016/j.bbr.2006.07.017)

Salmon P 2001 Effects of physical exercise on anxiety, depression, and sensitivity to stress: a unifying theory. Clinical Psychology Review 21 33-61. (https://doi.org/10.1016/S0272-7358(99)00032-X)

Schlittler M, Goiny M, Agudelo LZ, Venckunas T, Brazaitis M, Skurvydas A, Kamandulis S, Ruas JL, Erhardt S, Westerblad H, et al. 2016 Endurance exercise increases skeletal muscle kynurenine aminotransferases and plasma kynurenic acid in humans. American Journal of Physiology-Cell Physiology 310 C836-C840. (https://doi. org/10.1152/ajpcell.00053.2016)

Sciolino NR, Dishman RK \& Holmes PV 2012 Voluntary exercise offers anxiolytic potential and amplifies galanin gene expression in the locus coeruleus of the rat. Behavioural Brain Research 233 191-200. (https://doi.org/10.1016/j.bbr.2012.05.001)

Sciolino NR, Smith JM, Stranahan AM, Freeman KG, Edwards GL, Weinshenker D \& Holmes PV 2015 Galanin mediates features of neural and behavioral stress resilience afforded by exercise. Neuropharmacology 89 255-264. (https://doi.org/10.1016/j. neuropharm.2014.09.029)

Seo JS, Wei J, Qin L, Kim Y, Yan Z \& Greengard P 2016 Cellular and molecular basis for stress-induced depression. Molecular Psychiatry 22 1440-1447. (https://doi.org/10.1038/mp.2016.118)

Serchov T, Clement HW, Schwarz MK, Iasevoli F, Tosh DK, Idzko M, Jacobson KA, de Bartolomeis A, Normann C, Biber K, et al. 2015 Increased signaling via adenosine A1 receptors, sleep deprivation, imipramine, and ketamine inhibit depressive-like behavior via induction of homer1a. Neuron 87 549-562. (https://doi. org/10.1016/j.neuron.2015.07.010)

Sierakowiak A, Mattsson A, Gomez-Galan M, Feminia T, Graae L, Aski SN, Damberg P, Lindskog M, Brene S \& Aberg E 2014 Hippocampal morphology in a rat model of depression: the effects of physical activity. Open Neuroimaging Journal 9 1-6. (https://doi.org /10.2174/1874440001509010001)

Slattery DA \& Cryan JF 2012 Using the rat forced swim test to assess antidepressant-like activity in rodents. Nature Protocols 7 1009-1014. (https://doi.org/10.1038/nprot.2012.044)

Solberg LC, Horton TH \& Turek FW 1999 Circadian rhythms and depression: effects of exercise in an animal model. American Journal of Physiology 276 R152-R161. (https://doi.org/10.1152/ ajpcell.1999.276.1.C152)

Sothmann MS, Buckworth J, Claytor RP, Cox RH, White-Welkley JE \& Dishman RK 1996 Exercise training and the cross-stressor adaptation hypothesis. Exercise and Sport Sciences Reviews 24 267-287. (https:// doi.org/10.1249/00003677-199600240-00011)

Stephens T 1988 Physical activity and mental health in the United States and Canada: evidence from four population surveys. Preventive Medicine 17 35-47. (https://doi.org/10.1016/00917435(88)90070-9)

Steptoe A \& Butler N 1996 Sports participation and emotional wellbeing in adolescents. Lancet 347 1789-1792. (https://doi.org/10.1016/ S0140-6736(96)91616-5)

Steptoe A, Wardle J, Pollard TM, Canaan L \& Davies GJ 1996 Stress, social support and health-related behavior: a study of smoking, alcohol consumption and physical exercise. Journal of
Psychosomatic Research 41 171-180. (https://doi.org/10.1016/00223999(96)00095-5)

Steptoe A, Wardle J, Fuller R, Holte A, Justo J, Sanderman R \& Wichstrom L 1997 Leisure-time physical exercise: prevalence, attitudinal correlates, and behavioral correlates among young Europeans from 21 countries. Preventive Medicine 26 845-854. (https://doi.org/10.1006/pmed.1997.0224)

Stone EA \& Lin Y 2011 Open-space forced swim model of depression for mice. Current Protocols in Neuroscience Chapter 9 Unit9.36. (https:// doi.org/10.1002/0471142301.ns0936s54)

Stranahan AM, Khalil D \& Gould E 2006 Social isolation delays the positive effects of running on adult neurogenesis. Nature Neuroscience 9 526-533. (https://doi.org/10.1038/nn1668)

Stranahan AM, Lee K \& Mattson MP 2008 Central mechanisms of HPA axis regulation by voluntary exercise. NeuroMolecular Medicine 10 118-127. (https://doi.org/10.1007/s12017-008-8027-0)

Sun P, Wang F, Wang L, Zhang Y, Yamamoto R, Sugai T, Zhang Q, Wang Z \& Kato N 2011 Increase in cortical pyramidal cell excitability accompanies depression-like behavior in mice: a transcranial magnetic stimulation study. Journal of Neuroscience 31 16464-16472. (https://doi.org/10.1523/ JNEUROSCI.1542-11.2011)

Tharp GD 1975 The role of glucocorticoids in exercise. Medicine and Science in Sports 7 6-11.

Trost A \& Hauber W 2014 Dopamine D1/D2 receptors do not mediate the expression of conditioned place preference induced by the aftereffect of wheel running. BMC Neuroscience 15 124. (https://doi. org/10.1186/s12868-014-0124-4)

Troxell ML, Britton SL \& Koch LG 2003 Selected contribution: variation and heritability for the adaptational response to exercise in genetically heterogeneous rats. Journal of Applied Physiology 94 1674-1681. (https://doi.org/10.1152/japplphysiol.00851.2002)

Valentinuzzi VS, Scarbrough K, Takahashi JS \& Turek FW 1997 Effects of aging on the circadian rhythm of wheel-running activity in C57BL/6 mice. American Journal of Physiology 273 R1957-R1964. (https://doi. org/10.1152/ajpcell.1997.273.6.C1957)

Van Hoomissen JD, Chambliss HO, Holmes PV \& Dishman RK 2003 Effects of chronic exercise and imipramine on mRNA for BDNF after olfactory bulbectomy in rat. Brain Research 974 228-235. (https:// doi.org/10.1016/S0006-8993(03)02584-8)

van Praag H 2008 Neurogenesis and exercise: past and future directions. NeuroMolecular Medicine 10 128-140. (https://doi.org/10.1007/ s12017-008-8028-z)

van Praag H, Christie BR, Sejnowski TJ \& Gage FH 1999a Running enhances neurogenesis, learning, and long-term potentiation in mice. PNAS 96 13427-13431. (https://doi.org/10.1038/6368)

van Praag H, Kempermann G \& Gage FH 1999b Running increases cell proliferation and neurogenesis in the adult mouse dentate gyrus. Nature Neuroscience 2 266-270.

Vialou V, Robison AJ, Laplant QC, Covington HE 3rd, Dietz DM, Ohnishi YN, Mouzon E, Rush AJ 3rd, Watts EL, Wallace DL, et al. 2010 DeltaFosB in brain reward circuits mediates resilience to stress and antidepressant responses. Nature Neuroscience 13 745-752. (https://doi.org/10.1038/nn.2551)

Voss MW, Vivar C, Kramer AF \& van Praag H 2013 Bridging animal and human models of exercise-induced brain plasticity. Trends in Cognitive Sciences 17 525-544. (https://doi.org/10.1016/j. tics.2013.08.001)

Walker CD, Bath KG, Joels M, Korosi A, Larauche M, Lucassen PJ, Morris MJ, Raineki C, Roth TL, Sullivan RM, et al. 2017 Chronic early life stress induced by limited bedding and nesting (LBN) material in rodents: critical considerations of methodology, outcomes and translational potential. Stress 20 421-448. (https://doi. org/10.1080/102553890.2017.1343296)

Wallace DL, Han MH, Graham DL, Green TA, Vialou V, Iniguez SD, Cao JL, Kirk A, Chakravarty S, Kumar A, et al. 2009 CREB regulation 
of nucleus accumbens excitability mediates social isolation-induced behavioral deficits. Nature Neuroscience 12 200-209. (https://doi. org/10.1038/nn.2257)

Werme M, Messer C, Olson L, Gilden L, Thoren P, Nestler EJ \& Brene S 2002 Delta FosB regulates wheel running. Journal of Neuroscience 22 8133-8138.

Willner P 2005 Chronic mild stress (CMS) revisited: consistency and behavioural-neurobiological concordance in the effects of CMS. Neuropsychobiology 52 90-110. (https://doi.org/10.1159/000087097)

Willner P, Muscat R \& Papp M 1992 Chronic mild stress-induced anhedonia: a realistic animal model of depression. Neuroscience and Biobehavioral Reviews 16 525-534. (https://doi.org/10.1016/S01497634(05)80194-0)

Wook Koo J, Labonte B, Engmann O, Calipari ES, Juarez B, Lorsch Z, Walsh JJ, Friedman AK, Yorgason JT, Han MH, et al. 2016 Essential role of mesolimbic brain-derived neurotrophic factor in chronic social stress-induced depressive behaviors. Biological Psychiatry $\mathbf{8 0}$ 469-478. (https://doi.org/10.1016/j.biopsych.2015.12.009)

Wrann CD, White JP, Salogiannnis J, Laznik-Bogoslavski D, Wu J, Ma D, Lin JD, Greenberg ME \& Spiegelman BM 2013 Exercise induces hippocampal BDNF through a PGC-1alpha/FNDC5 pathway. Cell Metabolism 18 649-659. (https://doi.org/10.1016/j. cmet.2013.09.008)
Yau SY, Li A, Hoo RL, Ching YP, Christie BR, Lee TM, Xu A \& So KF 2014 Physical exercise-induced hippocampal neurogenesis and antidepressant effects are mediated by the adipocyte hormone adiponectin. PNAS 111 15810-15815. (https://doi.org/10.1073/ pnas.1415219111)

Yehuda R 2004 Risk and resilience in posttraumatic stress disorder. Journal of Clinical Psychiatry 65 (Supplement 1) 29-36.

Yehuda R, Flory JD, Southwick S \& Charney DS 2006 Developing an agenda for translational studies of resilience and vulnerability following trauma exposure. Annals of the New York Academy of Sciences 1071 379-396. (https://doi.org/10.1196/annals.1364.028)

Zheng H, Liu Y, Li W, Yang B, Chen D, Wang X, Jiang Z, Wang H, Wang Z, Cornelisson G, et al. 2006 Beneficial effects of exercise and its molecular mechanisms on depression in rats. Behavioural Brain Research 168 47-55. (https://doi.org/10.1016/j.bbr.2005.10.007)

Zhu X, Ottenheimer D \& DiLeone RJ 2016 Activity of D1/2 receptor expressing neurons in the nucleus accumbens regulates running, locomotion, and food intake. Frontiers in Behavioral Neuroscience 10 66. (https://doi.org/10.3389/fnbeh.2016.00066)

Zschucke E, Renneberg B, Dimeo F, Wustenberg T \& Strohle A 2015 The stress-buffering effect of acute exercise: evidence for HPA axis negative feedback. Psychoneuroendocrinology 51 414-425. (https://doi. org/10.1016/j.psyneuen.2014.10.019)

Received in final form 12 December 2017

Accepted 11 January 2018

Accepted Preprint published online 12 January 2018 